\title{
Adriaan Reland, Galatea: An Introduction
}

\author{
Dirk Sacré
}

Nescio quis furtim corda subintrat amor. ${ }^{1}$

For Adriaan Reland, writing Latin verse was not a whimsical or an eccentric activity. As a child, he had been encouraged to devote himself to the Latin Muse. He thus developed a passion that stayed with him throughout his life. In those days it was absolutely normal for a talented youngster to be trained in composing Latin hexameters and pentameters from an early age, upon entering the Latin school; nor was it unusual to continue to do so during one's academic years and even later on in life, at least if one was bestowed with literary perceptiveness. In Reland's case the first exhortations to try his hand at Latin poetry would have come from his father, Johannes Reland. Indeed, Johannes, an excellently educated pastor, was a devotee of Latin poetry: barely twelve years of age, he had written a Latin poem that had charmed a then renowned Neo-Latin poet; ${ }^{2}$ later on he abandoned the practice of writing Latin, his son's biographer tells us, but since his enthusiasm for the Muse remained unaltered, he incited his son to foster the Latin Muse whenever there was some spare time to do so. ${ }^{3}$ After his first training in a Latin school of Amsterdam, young Adriaan, eleven years old, entered the Athenaeum illustre in the same

1 Adriani Relandi poemata [...] (henceforth abbreviated as 'Reland, ed. Perrenot'), 'In nuptias [...] Adami Personi, et [...] Christinae Margaritae Nuckiae' (1701), p. 41, l. 40.

2 Joseph Serrurier refers to 'Brunonem celebrem inter nostros Poëtas' in his funeral oration for Adriaan Reland (March 1718), the text of which one can read in Relandi Galatea, ed. P. Bosscha (Amsterdam, 1809) (henceforth abbreviated as 'Reland, ed. Bosscha'), p. 10. The poet in question must have been Henricus Bruno (c. 1620-1664), who is best known as the private tutor (1638-1647) to the children of Constantijn Huygens, and later on as a teacher in Hoorn (1649-166o), and whose Latin and Dutch output was gathered after his death in a book entitled Mengel-moes van verscheyde gedichten [...] (1666). On Bruno one can consult (on the Internet) Leek, Maar ingeboren aard gaat alle dwang te boven.

3 A classical exercise consisted in writing letters in Latin prose and verse to his father and the latter's friends (Serrurier in Reland, ed. Bosscha, p. 10). 
city, where, for three years (1687-c. 169o), he was schooled by Petrus Francius $\left(1645^{-1704)}\right.$, at the time not only a famous Latin poet whose Ovidian style was highly admired, but also a master in rhetorical style and in oratorical delivery. ${ }^{4}$ Thus, the foundations of Adriaan Reland's dedication to the Latin Muse were laid both in his parental home and in Amsterdam. We do not know if his subsequent years as a student at Utrecht and Leiden put him in contact with other aficionados of Neo-Latin poetry, but during this period he must have been working on the elegies that would establish his reputation as a poet. After his appointment as a professor in Harderwijk (1700) and, a year later, at Utrecht University, where he remained until his death, he occasionally produced more Latin poems. Occasionally, for his poetic output in Latin remained limited. ${ }^{5}$ As far as I can see, three of his compositions became widely renowned. The poetic epitaph he had written for himself in six elegiac couplets found its way into the funeral oration, which was delivered and published by his colleague Joseph Serrurier (1663-1742), from where it pops up in a number of articles devoted to Reland's death in the international scholarly press. ${ }^{6}$ It elaborated on the traditional themes of the inevitability of death and the necessity to foster the soul rather than the body, to display Christian morals and to worship God. Reland's enthusiastic lyric poem in praise of Lucretius, then, reached an audience beyond the traditional Latin readership, for it was also included in an early Dutch translation of Rome's major Epicurean poet. ${ }^{7}$

But Reland's fame as a Latin poet is based mainly on a small collection of thirteen love elegies, entitled Galatea. Lusus poeticus and first published in Amsterdam in the same year (1701) in which he was appointed professor at Utrecht and his Ode in poësin Lucretianam came out. Galatea was reissued in Utrecht in 1710. The booklet outlived its author; its lasting success is proved by a fair number of reissues in the course of the eighteenth century: Utrecht,

4 On Francius, see Heesakkers, 'An Lipsio licuit'; Van Miert, Illuster onderwijs.

5 Cf. Reland, ed. Perrenot, pp. 39-153 (23 elegies, 9 lyrical poems, 20 epigrams and 3 paraphrases of Horace). Writing in Dutch was not his cup of tea, he says in a poem (cf. Reland, ed. Perrenot, p. 43 [1702], ll. 5-6: 'Prae patrio Latii teneor sermonis amore, / aspirat genio non satis ille meo'- 'The love for the Latin tongue has much more power over me than the love for my native language, which does not inspire my talents as much').

6 Reland, ed. Bosscha, p. 35. From there, it appeared e.g. in 'D'Utrecht', in L'Europe savante, pp. 290-295; 'Article XV. Eloge de M. Adrien Reland, nouvellement mort Professeur (...)', in Histoire critique de la Republique des Lettres, vol. 15, pp. 412-446; Burmannus, Traiectum eruditum, virorum doctrina illustrium, p. 295; obviously also in Reland, ed. Perrenot, p. 149.

7 It was included in De werken van T. Lucretius Carus van het heelal (the Latin text of Lucretius was added). One finds an (above all metrical) analysis of Reland's poem in Bernays, 'Hadrian Relands Lobgedicht auf Lukrez', pp. $5^{-21}$. Part of Reland's poem was quoted by Goethe. 
1718; ${ }^{8}$ Utrecht, 1724; Franeker, $1735 ;^{9}$ Franeker, 1738; Amsterdam, 1739; Franeker, 1747; Utrecht 1748 (in a volume of collected verses of Reland, produced by Abraham Perrenot). The collection was even reedited in the first half of the nineteenth century, when the long-lived vogue of Neo-Latin poetry was on the wane: in Amsterdam in 1809, young Petrus Bosscha (1789-1871) reissued the cycle with a rich apparatus of loci similes, ${ }^{10}$ and in Germany, the Latin teacher Carl F.G. Siedhof $\left(1803^{-}-\right.$. 1866) released a slightly reworked version of Bosscha's edition in the same year in which he emigrated to the United States (Stuttgart, 1845).11 Furthermore, some distinguished Dutch Neo-Latin poets of the second half of the eighteenth century, such as Laurentius Santenius (van Santen, 1746-1798) and Henricus Waardenburg (1760-1812), had read the Galatea with such enthusiasm that they engaged in an inquiry into the sources of his verses and into loci similes in ancient and modern Latin poetry. ${ }^{12}$ Moreover, Galatea was translated into Dutch verse (Utrecht, 1837) by Roelof Hendrik Graadt Jonckers (1805-1886), who also authored Latin poems. ${ }^{13}$ As a matter of fact, already a century before, one of the poems of the cycle had been imitated in French verse by an anonymous poet ('J. O ... M.... D.M.'), whose adaptation was published in London in $1738 .{ }^{14}$ Some of the elegies must have also appeared in a Dutch translation, made by the Dutch and Neo-Latin poet Ernestus Gulielmus Higtius (Higt, $1723-1762),{ }^{15}$ another Dutch rendering of the entire cycle was prepared by the well-known translator Antoni Hartsen

8 In the catalogue of the Zentralbibliothek of Zürich, mention is made of an edition, Utrecht, 1728 (not seen); this might be a typo for Utrecht, 1718 .

9 This edition contains (pp. 29-32) an occasional elegy (Elegia ad [...] Gulielmum Bentingium [...] peregre proficiscentem), which corresponds to Reland, ed. Perrenot, pp. 48-53.

10 Later on, the same Bosscha also produced an edition of the works of Janus Secundus (1511-1536) with notes of Petrus Burmannus and of his own, in which he occasionally referred to Reland: see, for instance, Ioannis Nicolai Secundi Hagani Opera omnia, emendatius et cum notis adhuc ineditis Petri Burmanni Secundi denuo edita, p. 31 (ad Secundus, eleg. 1, 5, 23).

11 Siedhof (ed.), Hadriani Relandi Galatea cum Petri Bosscha notis selectis. The preface was completed in Aurich in June 1844. On Siedhof, see Schröder, 'Carl Siedhof, Elegia in obitum F.J. Muelleri', pp. 313-343.

12 They handed their annotations over to Bosscha, who incorporated them in his own notes: Reland, ed. Bosscha, p. viII (in the Preface to the reader).

13 Relands Galatea. Eene dichterlijke speling (1837).

14 'Imitation de la XII. Élégie latine d'Adrien Reland, sur la mort de Galatée', in Pièces libres de M. Ferrand, et poësies de quelques autres auteurs sur divers sujets, pp. 95-102. The translator meant the 13th, not the 12th elegy.

15 Reland, ed. Bosscha mentions the translations (preface, p. x); the information is confirmed by Annaeus Ypey (176o-1837), who produced a selection of Dutch and Latin poems of Higtius, and in his introduction pointed out that Higt had translated the 2nd, 3rd, 4th,

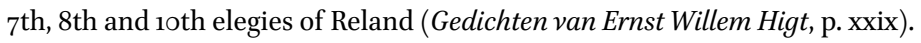


(1719-1782), whose versions, however, remained unpublished. ${ }^{16}$ Towards the end of the last century, J.P. Guépin translated the tenth elegy into Dutch verse. ${ }^{17}$

Among the advocates of modern Latin poetry, Reland was not forgotten. The Neo-Latin poet Gerardus David Jordensius (1731-1803) from Deventer, for instance, listed Galatea among the models he followed in his own love poetry.18 His aforementioned colleague Laurentius Santenius (van Santen, 1746-1798) hoped that his own small booklet of (only five) love elegies for a girl called Ida would stand the test of time, just as Reland's Galatea did..$^{19}$ Some poets writing cycles of amatory elegies and adding the words 'lusus poeticus' to their titles ${ }^{20}$ were actually imitators of Reland or were well acquainted with his volume: apart from the aforementioned Jordensius and Santenius, two students must be adduced here, whose works went into print: Johannes Adamus Nodellus (1754-1814) and Dionysius J.G. de la Houssaye (c. 176o-1796): the former had his Regina. Lusus poeticus published in Franeker in 1775, the latter his Amaryllis. Lusus poeticus in Groningen in 1782; the former structured his volume in thirteen elegies, as Reland had done, and borrowed quite some motifs and expressions from his model; ${ }^{21}$ the latter inserted in his cycle a kind of heroid addressed to the beloved, as Relandus had done, and lamented his mistress'

16 Reland, ed. Bosscha, p. $\mathrm{x}$, has a reference to these renderings, and states that the manuscript was still in the possession of Hartsen's son Cornelis (1751-1817) around 1809. These Dutch versions have survived and are now kept at the Royal Library at The Hague (KA CLXXX (Diligentia Omnia), part IV [mentioned online]); they date from 1769. Hitherto, I have been unable to consult yet another (it seems) Dutch translation of some poems, which is said to have been published in volumes two and three of the Dutch journal De Nederlandsche Spectator, c. 1857.

17 Guépin, Typisch Nederlands. De Latijnse poëzie, pp. 65-73.

18 Jordensius, Gellia. Lusus poeticus, el. 11, p. 45: 'Hic formosa suum sequitur Galatea Relandum'. On Jordensius, see Bedaux, 'Gerhard David Jordens (1734-1803), neulateinischer Dichter aus Deventer', pp. $773^{-} 790$ (pp. $782-785$ on Gellia).

19 Cf. Schouten, 'Die Ida von Laurens van Santen: Einleitung-Text-Kommentar', p. 274 (third elegy, lines 29-30: 'Tunc venia, Relande, tua veniaque Secundi / et mea me nomen vate puella petet'.). The full title of Santenius' booklet was Ida, Lusus poeticus (1773).

20 Cf. Bedaux, 'Gerhard David Jordens', p. 784.

21 There are some liminary poems, in which the link with Reland is established. Thus, to give just one example here, Theodorus Kootenius (van Kooten, 1749-1813) joined Nodell to Janus Secundus and Reland in his In Reginam [...] ab Johanne Adamo Nodell celebratam (fol. *4r: 'Sic, ubi discetur teneri Galatea Relandi / Juliaque Hagani maxima fama soli, / has etiam celebrere inter Regina Nodelli, / teque legens laudet serus ametque nepos!'). So did Nodell himself, too, in the first elegy (pp. 4-5): 'Dum Galatea suo nuper cantata Relando / Juliaque, aeternum qua tulit Haga decus, / forsan et has inter juvenis Regina Nodelli / vivet, in Idaliis nomen adepta jugis'. Two years later, Nodell published a sequel to his booklet (Johannis Adami Nodell Regina, lusus poëticus. Liber alter (1777) (ten elegies, in which the influence of Reland is observable again). 
death by drowning (Amaryllis thus shared the fate of Galatea); here too, the dependence on Reland is obvious. From these students' works, it becomes clear that Galatea was effectively proposed to pupils and students as a model to emulate.

The famous critic P.H. Peerlkamp (1786-1865) spoke very favourably of the professor's love elegies; though Peerlkamp was at times a severe judge of Neo-Latin poetry, he remarked on Galatea that it was of a divine beauty ('Caeterum Galatea est divini plane decoris'). ${ }^{22}$ The philologist and poet Lucian Müller (1836-1898) ranked the 'zierliche Dichter der Galatea' among the best poets of his age. ${ }^{23}$ Actually, a double, slightly contradictory topos popped up in assessments of Reland's literary merits: it was repeated, on the one hand, that with respect to popularity, his slim booklet of love poems equalled his many, often bulky, scholarly works, and, on the other, that his love poems made it clear what an accomplished and unique poet Reland would have become if he had persevered in his poetic endeavours. ${ }^{24}$

Anyhow, as we just saw, Reland's juvenile book of elegies was not a complete farewell to the Latin Muse. Nor did Reland immediately take leave of his persona as a passionate lover of the girl he called Galatea in his elegies. Thus, he also referred to the death of Galatea in a wedding poem written around the same time (c. 1701-1702) ${ }^{25}$ By portraying himself as the author of the booklet, he seemed to indicate that the elegies had had a certain success.

Be that as it may, not only did Reland refer to his alter ego as a lover of Galatea in another poem, he also continued to polish and work on his verses for Galatea after their first publication in 1701. The title and subtitle of the booklet remained unaltered. The subtitle, Lusus, has some particular overtones. In antiquity, the noun was particularly used for various types of lighter

22 Peerlkamp, Liber de vita doctrina et facultate Nederlandorum qui carmina Latina composuerunt, pp. 469-472, at p. 471.

23 Geschichte der klassischen Philologie in den Niederlanden, p. 212.

24 See, e.g., Peerlkamp, Liber, p. 470: 'libello, quo tantam adeptus est gloriam, ut omnia ejus de literis Orientalibus scripta, quamvis summae doctrinae et acutissimi judicii, non magis celebrata sint, quam unicus iste ingenii poëtici lusus'; Serrurier in Reland, ed. Bosscha, pp. 9-10: 'ut poëtices quoque sibi facultatem compararet, in quâ quantum excelluerit, et quam proclive ipsi fuisset in summum Poëtam evadere, si non se altioribus ac severioribus disciplinis totum tradidisset, vel Lusus eius poëtici [...] luculenter ostendunt'; Kampen, Beknopte geschiedenis der letteren en wetenschappen in de Nederlanden (...), vol. 1, p. 426, and vol. 3, pp. 126-127; Niceron, Mémoires pour servir à l'histoire des hommes illustres dans la République des Lettres, vol. 1, p. 336.

25 'Nicolao Bidloo medico, lectissimam virginem Nicolaam Clusiam ducenti', in Reland, ed. Perrenot, pp. 41-42 (p. 42: 'Me quoque destituit pallentem virgine Phoebus, / quae spolium nostri sola caloris habet. / Nunc secum Galatea meos exstinxit amores'). 
and shorter poetry, for non-epic poems. By adding 'lusus' — to my knowledge very few other Neo-Latin cycles of erotic elegies have the same subtitle-, ${ }^{26}$ the poet also stresses the playfulness of the collection of poems, possibly suggesting that it was above all an exercise-like product of his literary creativity and skills. Finally, the subtitle reminds us of a famous collection of very varied (lyrical, epigrammatical, elegiac, pastoral) poems written by Andreas Naugerius (Navagero, 1483-1529), which contains, among other things, love poems for such girls as Gellia and Hyella, and in which, in spite of its variety, a pastoral element prevails; Galatea, too, whose name often occurs in vernacular and in Neo-Latin poetry, reminds us particularly of the homonymous girl, the mistress of some shepherds in Vergil's pastoral eclogues; furthermore, she also is a Nereid. ${ }^{27}$ In any case, it is hardly conceivable that Reland would not have read Navagero's immensely popular work as intensely as Virgil's Bucolics.

Whereas the title Galatea. Lusus poeticus was not changed, many a verse was reworked. Reland manifestly tried to improve some passages and lines until the last years of his life. There is some confusion in later accounts about the first edition (Amsterdam, 1701 ) ${ }^{28}$ It is not true that the booklet came out anonymously. ${ }^{29}$ On the contrary, it mentions the poet's name together with his qualification as a professor at Utrecht, which implies that the volume came out after February 21, 1701. Yet, it is correct that the edition conveys the impression that an editor, whose name is not mentioned, but who was a friend of the poet, had laid hands on the elegies and had these published without Reland being involved in the edition. The preface to the reader states that the author himself would not have issued these not so austere products of his youth, and that it was a friend, who was impressed by the Ovidian elegance of the poems, who had them printed, the more readily so, because there was nothing offensive to be found in these elegies. It is not impossible that this is the real truth; but it is

26 That is, before Galatea came out. On four later poets, who had a lusus poeticus published after Reland and were familiar with his volume, see supra, p. 246.

27 For the humanist genre of the lusus and its links with erotic poetry, see Ferroni, Dulces lusus. Lirica pastorale e libri di poesia nel Cinquecento. As a Nereid, the name Galatea occurs for instance in the erotic elegies of Propertius $(1,8,18$ [and 3, 2, 7]) and Ovid (Amores, 2, 11, 34). In my opinion, there is no irony of Reland in the fact that the latter has his beloved Galatea die at sea.

28 Adriani Relandi Orientalium Linguarum in Acad: Trajectinâ Professoris Galatea. Lusus poeticus. No printer is mentioned.

29 This was erroneously asserted in Reland, ed. Bosscha, p. ix ('ipsam principem editionem, quae anno 1701, sine nomine auctoris, prodiit'); Peerlkamp repeated it in his Liber, p. 470 ('Galatea primum prodiit $\mathrm{A}^{\circ}$. 1701, auctore non nominato'). Guépin, Typisch Nederlands, p. 65 , too, intimated that the poet's name was not mentioned on the title page before the posthumous edition of Franeker, 1735 . 
equally possible that it was a fiction, made up by the poet himself. Maybe the edition was an exercise in presenting a side-product of his scholarly work. Or perhaps designating the booklet as a product issued without the involvement of its author was a way to make the publication more acceptable: as a university professor, Reland could issue occasional love poems (his teacher Francius had done the same), but was not expected to indulge in composing full cycles of erotic poetry, which was more something for a youngster or a non-academic. ${ }^{30}$ Therefore, the preface labels the poems as juvenile products ('ineunte aetatis flore' $)^{31}$ which the author himself would not have sent to press. Anyhow, the very presence of a preface and especially of a dedicatory poem turns the book into a full and genuine edition. The dedicatory poem is addressed by Reland to his former teacher Petrus Francius and contains a trope in this genre of verse: ${ }^{32}$ if the elegies have any merits, these are due to the poet's immensely talented teacher; the latter is asked to indicate whatever is poor in the booklet and to have it removed.

Now, confronting the successive editions of Galatea, one can ascertain that the poet took a lasting interest in his collection of elegies, for one finds more than seventy variant readings, some of which are minor variants, while other ones are more substantial, including additions or omissions of entire lines or elegiac couplets. Most of the changes were introduced in the second edition (1710). This is not the place to discuss all these variants, let alone present a critical edition of the collection. It may be enough to quote some examples in order to show how, during a decade at least, Reland must have been rereading and refining his poems. Quite often, one witnesses how he was searching for better, more classical, more sophisticated, more effective words or expressions. ${ }^{33}$ In elegy 2, 14 he changed the prosaic and logically less fitting word 'portare' into

30 Cf. Van Dam, 'Daniel Heinsius' Erstlingswerk. Prolegomena zu einer Edition der Monobiblos', p. 175. This mentality was typical of the Renaissance and the early seventeenth century; I assume it had not changed by 1700.

31 Preface: 'Elegans hoc carmen invidisset suo seculo Poeta, quod plurima carmina ineunte aetatis flore ducta, iis forte qui supercilium non satis ponunt, minus grata fore verebatur: sed dandum est aliquid aetati: hi Lusus suo auctori fere subducti sunt, nec carmina haec [...] ipse Cl. Relandus, unquam ediderat nisi ejus amicus, inscio auctore, illa praelo commisisset". Compare Serrurier in Reland, ed. Bosscha, p. 10: 'Lusus eius poëtici, quos admodum adolescens conscripsit'.

32 Loyalty and gratitude towards his former preceptors were of paramount importance to Reland, it seems: cf. Serrurier in Reland, ed. Bosscha, p. 21.

33 He also corrected one or two errors from the first edition. Thus the form 'concepta' in $\mathrm{el}$. 4, 19-20 ('Spes mea, concepta ne dedignare calores, / et tibi devotae suscipe mentis opus') made no sense and was replaced by 'conceptos' (going with 'calores') from the second one onwards. 
the better 'gignere', so that 'Nescitis, miseri, quot mala portet amor' became 'Nescitis, miseri, quot mala gignat amor'; in line 11 of the same poem, the stock expression 'extinguere flammas' was replaced by the more refined 'necare favillas'. In el. 4, 23-24, one finds, in the first edition 'Cara puella, puella oculis mihi carior ipsis, / aut oculis si quid carius esse potest' ('Dearest girl, girl dearer to me than my own eyes, or if anything could be dearer to my than my eyes'), a nice couplet with striking repetitions of 'puella', 'oculi' and 'carus', the pentameter of which owed much to Catullus: ${ }^{34}$ afterwards, the poet decided to stress even more the central idea of 'dearness' ('cara'), introducing an additional polyptoton and giving the eyes of the beloved a more expressive place in the lines: 'Cara puella, puella oculis mihi carior ipsis, / et si quid caris carius est oculis' ('Dearest girl, girl dearer to me than my own eyes and whatever is dearer than my dear eyes'). In $e l .5,7$, addressed to Galatea, who is said to be unwell, the poetic stock-phrase for a person suffering from fever, "Flamma tuos artus agitat' (1701) was conveniently changed into the more sophisticated 'Adducti livent artus' (1710), where 'adductus' hints at the stiffness and the weakening of the ill person's limbs, while 'livere' aptly introduces her pale complexion. ${ }^{35}$ A few verses later, Reland decided to cut the all too obvious repetition of the Petrarchan opposition between heat (fever) and cold (the icy water that caused the illness), expressed in these lines: 'O rerum fatique vices! Quis dixerit unquam, / ut calor e gelidis surgere possit aquis? / Attamen heic mediis, quae semina duxit ab undis, / et male, captato frigore, flamma furit' ('O the vicissitude of things and of fate! Who would ever say that heat can arise from icy waters? Yet here, a flame is violently raging, kindled in the midst of water and a cold miserably caught') (1701), and to compress the idea into one couplet: 'Scilicet hîc, gelidis quae semina duxit ab undis, / et male captato frigore, flamma furit'. In $e l .10,1$, the poet, who had labelled himself anonymously as 'poeta', now somewhat more confidently used his own name, while playing with the ambiguous identity of the amator and the person of the poet: 'Pars animae, Galatea, meae, si cura poetae' (1701) became 'Pars animae, Galatea, meae, si cura Relandi'.36

34 Catullus, 82, 2: at aliud, si quid carius est oculis.

35 Moreover, 'Flamma tuos artus agitat' was too erotic, coming after 'torreris ab aestu' (1), 'exuritque ['exaratque' in the first edition was a misprint] tuas infelix cura medullas' (3): the impression could arise that Galatea's feverishness was a sign of her being in lovewhich was too explicit in that context. But cf. also Ovid, Heroides, 11, 29.

$36 \quad$ It was typical of the (Neo-)Latin elegy that the poet's real name was kept, while the (real or fictitious) beloved was given an allonym (in the Neo-Latin tradition, most often a classicising pseudonym). Compare, for instance, Propertius, 3, 10, 15: dein qua primum oculos cepisti veste Properti; Ovid, Amores, 2, 13, 25: adiciam titulum 'servata Naso Corinna'. 
In the subsequent editions produced during the poet's lifetime and shortly after his death, only a few changes were introduced, possibly on the basis of marginal emendations the poet had added to his printed copy. ${ }^{37}$ But his lifelong commitment to his elegies can be deduced-be it with some circumspection-from an edition that appeared thirty years after the poet's death (Utrecht, 1748), thanks to the zeal of Abraham Perrenot (1726-1784), a jurist who had just obtained his Master's degree from Utrecht University, for Perrenot brought together Reland's entire verse production, whether it had appeared in print or had remained in manuscript form and had been respectfully kept by the late poet's acquaintances. He had had access to at least two printed copies of Galatea containing variants proposed by the poet himself (he was sure about that), one in Leiden University ${ }^{38}$ and another one containing copies of Reland's marginal notes, made by an unnamed scholar with a great interest in poetry. ${ }^{39}$ In his edition of Galatea, Perrenot thus introduced the new variants at issue (or maybe a selection from what the marginalia offered). ${ }^{40}$ Indeed, in some six places (el. 3, 17; 8, 15-16; 8, 18;11, 34; 11, 35-36; 11, 43), we are confronted with new variants that might have sprung from the mind and pen of Reland; in any case, the new variants furnish a text that is more satisfactory from a linguistic point of view. Thus, in $e l .11,34$ 'provehere ratem' was changed into 'ferre per alta ratem', and in el. $8,15^{-16}$, the inelegant expression 'oculis adhibere fidem' was removed in favour of the better 'oculis credere'. ${ }^{41}$

The 1748 text was altered yet another time in 1809 , by the editor Petrus Bosscha, who silently intervened in two verses. His variants have no real value for the constitution of the text: Bosscha did not see any manuscript; he had not even been able to consult the first edition. Yet, in $e l .8,3$ he changed 'Flectere millenae quod non potuere puellae' into 'Flectere millenae quem non potuere puellae', thus introducing an unnecessary lectio facilior ('quem' referring to

37 E.g., in the third edition (Utrecht, 1718) one finds for the first time 'ne dedignere' instead of 'ne dedignare' (1701, 1710).

38 Which he obtained from the theologian and philologist Iohannes Alberti (1698-1762), professor of theology at Leiden and at the time rector of the University.

39 Reland, ed. Perrenot (in the preface to the reader, no pages). Perrenot had to rely on copies of the manuscripts, he says in the preface, and could not consult autograph manuscripts.

40 He was proud that this had enabled him to produce a better edition of the cycle, as he stated in his dedicatory poem, addressed to the jurist and philologist Petrus Wesselingius (1692-1764) (fol. [ $\left.\left.{ }^{*} 3\right] \mathrm{r}\right)$ : 'comtior auctoris nunc Galatea manu').

41 An analogous example of variants introduced after the death of a poet one finds in the poems of Laurentius Santenius (van Santen, 1746-1798), edited by Hoeufft, who claimed to have followed the voluntas auctoris: see Laur. Santenii Poëmata, p. LXII; contrary to what he declared in his preface, Hoeufft introduced quite an important number of variants (cf. Schouten, 'Die Ida von Laurens van Santen', p. 268). 
a friend who is in love), whereas 'quod', repeated from line 1, depended on the noun 'pectus' mentioned in the initial verse. And in el. 12, 27 he replaced the logical form 'tacitum' ('Haec ego dum meditor, tacitum mirantur amici') by 'taciti', referring to 'amici', unjustly, it seems to me, since these friends are speaking in the next verse ('dicunt'). So Bosscha's modifications can be easily dismissed. Their endorsement is a bit surprising, for if it is true that in other instances the scholar slightly criticised a word or an expression for being less felicitous and even suggested a better solution, he did so in the notes only, ergo without altering the text itself. ${ }^{42}$ Indeed, Bosscha seems not to have agreed completely with Perrenot's encomiastic thesis that the Galatea cycle could have been the work of an ancient Roman author ('quem Roma suum poterat dixisse libellum' - a booklet that Rome could have called her own) and that Reland had to be considered a 'poëta magnus etiam inter maximos' ('a great poet, even among the greatest').$^{43}$ In an admittedly small number of cases, the twenty-year-old scholar, very eager to put his philological knowledge on display, somewhat disapproved of the lexical choices made by Reland or considered that some expressions did not fit the stylistic register that was required in a given context. Thus, he objected to the use of a neologism in $\mathrm{el} .11,64,{ }^{44}$ criticised with some reason the use of 'transpirare' in $e l .7,45$, and not unjustly noted $(e l .10,122)$ that in the fervent context of the tenth elegy, where the lover begs his absent mistress to write to him, the second half of the pentameter is too passionless: ' $\mathrm{Tu}$, precor, absentis memorem te vivere nostri / scribe, nisi scripto sis prior ipsa tuo' ('You, please write a letter saying that you remember

42 For instance in el. 1, 16; el. 6, 6o (where, though without having detected an inaccuracy of the poet, Bosscha thinks that he can do better than Reland, yet proposes too rhetorical a couplet); el. 10, 122.

43 In the dedication poem (fol. [ $\left.{ }^{*} 2\right] \mathrm{v}$ ) and in the preface to the reader (fol. [ $\left.\left.{ }^{*} 4\right] \mathrm{r}\right)$.

44 Where we can read 'nabilis' instead of the classical 'innabilis'; 'nabilis' is not to be found in ancient texts; it occurs from the Middle Ages on and is attested in Neo-Latin poetry, e.g., in the early eighteenth-century epic Columbus by Ubertinus Carrara $(5,14$ and 5 , 117 ). An occasional and moderate use of neologisms was tolerated in Neo-Latin poetry, it seems to me (Janus Secundus, too, had coined a few neologisms, mostly diminutives and composita). A much less elegant neologism (influenced by the vernacular) of Reland is 'transpirare' in el. 7, 45 ('nocturnum transpirans dextera rorem'). Finally, a seemingly new word is Reland's 'ameletides' in $e l .12,43$, which stands for a kind of pad worn by women under the shoulder-blades. This is actually a false reading one will not find in the Thesaurus linguae Latinae, in Forcellini's Lexicon totius Latinitatis or in the Oxford Latin Dictionary, but which was largely accepted during the Renaissance (and until the nineteenth century) in a passage from Ovid's Ars amatoria $(3,273)$, where our modern editions read 'analectrides' or even more often 'analeptrides' (the Thesaurus linguae Latinae still has 'analeptides'). 'Ameletides', however, is mentioned in Stephanus, Thesaurus linguae Latinae, p. 188. 
me in my absence-unless you yourself come earlier than your letter'): there, he says, a pentameter like 'Rescribe: at scripto sis prior ipsa tuo' would do better. In a few other instances, he remarks that a word is less appropriate from a classical point of view, but that the word under discussion occurs often in Neo-Latin: thus in el. 2, 34, Bosscha perhaps rightly labelled 'basium' as a noun eschewed by ancient elegiac poets, but was aware of its frequency in the Neo-Latin elegy. In el. 3, 37 he disliked the use of the adverb 'ergo' with a shortened second syllable; but it seems to me that it is rather the recurrence of 'ergone' ('ergo' with the interrogative particle '-ne') that is awkward from an ancient perspective. ${ }^{45}$ Peerlkamp, too, objected to one specific passage as inferior: perhaps correctly, he found that the parenthesis 'o quanta molestia' in el. 7,15 was too prosaic and not passionate enough for a lover suffering from insomnia. ${ }^{46}$ These remarks make clear that some nineteenth-century philologists were still extremely sensitive to the formal aspects of humanist and post-humanist poetry; their observations should also be considered from a pedagogical perspective: Bosscha's edition (most unambiguous is the letter to Bosscha, written by another Neo-Latin poet, Hieronymus Boschius (de Bosch, 1740-1811) and included in the preliminary matters of this edition) reveals that he considered Galatea for the larger part as a model youngsters should follow while trying their hand at writing Latin verse, an exercise of paramount educational value.

How was a young poet expected to write amatory poetry in which he himself or an alter ego of his featured as the lover? A large scale of possibilities was at his disposal, and several ancient and Neo-Latin models could be imitated. ${ }^{47}$ Fundamentally, he had to make a choice between lyrical forms (Horatian odes, for instance, or hendecasyllables), hexameter lines (e.g., disguising himself as a shepherd living in a bucolic setting and depicting his love for a girl, who had to have a rural character) or elegiac forms. If he opted for the amatory elegy, his basic ancient models would be Propertius, Tibullus and Ovid, the three classical representatives of the Latin genre; but he would also have an eye for the sixth-century poet Maximianus, whose poems were considered by some at the

45 Reland often used it in Galatea (el. 3, 37; 5, 1; 9, 3; 13, 25) and in his other poems (e.g., in his Piae memoriae Augustissimae ac Illustrissimae Brittanniarum Reginae Mariae Stuart S. [Reland, ed. Perrenot, p. 73, line 3]: 'Ergone, quo me fata trahunt comes ire dolori'). One finds it also in other Neo-Latin poets (see, e.g., Secundus, Odae, 10, 1: 'Ergone vitae quod superest meae').

46 Furthermore, Peerlkamp was perhaps right in pointing at a logical flaw in el. 8, 1-2.

47 For the Neo-Latin love elegy, see, e.g., Parker, 'Renaissance Latin Elegy', pp. 476-488; Houghton, 'Renaissance Latin love elegy', pp. 290-305; Id., 'Elegy', in Moul (ed.), A Guide to Neo-Latin Literature, pp. 98-112; Moul, 'Lyric Poetry', pp. 41-56. 
time to be the work of Cornelius Gallus, commonly believed to have introduced the elegy in Rome. ${ }^{48}$ In the company of the three elegists he would also place Catullus, though a large part of the latter's love poems was written in lyrical verse; but in the Renaissance and later on, Catullus was often edited together with Tibullus and Propertius. ${ }^{49}$ Moreover, nothing could keep him from working with love stories as told in, for instance, the fourth book of the Aeneid, in the Metamorphoses or in the Heroids of Ovid. Obviously, a late-seventeenth or an early eighteenth-century Latin poet could profit from the incredible wealth of Neo-Latin amatory elegies written since the dawn of humanism by poets active all over Europe, not in the least in Holland, some of whom had acquired a long-lasting reputation and were reissued time and again..$^{50} \mathrm{He}$ could even peruse anthologies of Neo-Latin love poetry: the Veneres Blyenburgicae, for instance, issued in 1600 by Damasus Blyenburgius (1558-1616), proposed a cornucopia of poems, arranged by topic, and comprising some $95^{\circ}$ pages. ${ }^{51}$ Finally, this Neo-Latin poet would not dispense with some major vernacular love poets, such as Petrarch, ${ }^{52}$ to name the most famous one.

The classical models would offer examples to the modern poet of how to develop the theme of love in poetry and would supply a great quantity of tropes to be used in the amatory elegy; from the Neo-Latin models in particular, the poet would learn how to adapt ancient stories, to rephrase commonplaces or to transform and to enrich them. Moreover, following the ancient practice, the poet had the possibility to either devote an entire book (or a number of books) to a single romance, or to develop the love theme in a limited number of elegies, intertwining them with poems on other subjects. Furthermore, he could give an account of his affair with a single beloved person (in ancient times a

48 Cf., e.g, Consolino, 'L'elegia secondo Massimiano', pp. 183-224; D’Amanti, 'Massimiano e la pseudepigrafia di Pomponio Gaurico', pp. 47-64.

49 See, for instance, Catulli, Tibulli, Propertii nova editio, ed. Scaliger (1577); Catulli, Tibulli, Propertii opera (1749). Janus Secundus, too, had had no qualms about borrowing a line from Catullus that did not belong to the latter's elegiac poems in his Julia, 8, 5: 'quantum nulla fuit, quantum nec amabitur ulla'; cf. Catullus, 8, 5: 'amata nobis quantum amabitur nulla'.

$5^{\circ}$ An example one can find in Jordensius's erotic cycle Gellia, where the final poem explicitly places the love poems for Gellia in the tradition of Ovid, Tibullus, Catullus, Propertius, and, for the Neo-Latin part, Marcus Antonius Flaminius, Petrus Bembus, Georgius Sabinus, Andreas Naugerius, Franciscus M. Molza, Petrus Lotichius, Janus Secundus, Janus Broukhusius, and ... Reland (see n. 18 above). This catalogue in itself should probably be seen as a remake of a similar list of ancient Roman love poets, drawn up by Propertius, 2, $34,85^{-94}$.

$5^{1} \quad$ Veneres Blyenburgicae, sive Amorum hortus (1600).

52 And Petrarch himself influenced many Neo-Latin and vernacular poets: see, for instance, Forster, The Icy Fire, and, for Dutch literature, Ypes, Petrarca in de Nederlandse letterkunde. 
beautiful woman or a man, since the Renaissance usually a young woman), or unfold more than one romance. He did not necessarily have to describe an entire love story, and could confine himself to a few episodes taken from a liaison. Happy loves were not excluded, but they were rare; most of the time, amatory elegies told a story with an unhappy ending.

Reland's Galatea conforms to this general practice. It is the story of a love that had never been consummated and had ended with the death of the mistress. ${ }^{53}$ It starts with the lover's confession of an ardent desire for a girl who shows no particular interest in him; therefore the poet will utter his feelings in his poetry alone (el. 1). In $e l .2$, the poet describes the divine beauty of the girl, which explains why he feels such an ardent desire for her and may seem to have lost self-control. In the next elegy, passionate amour is compared to a more moderate and lifelong affection of love; the poet realises that he can only dream of such a relationship, in his poetry. In el. 4 , the poet declares his intense feelings of love for the beautiful Galatea. In el. 5, Galatea is sick; she suffers from a fever; in a similar fashion, the poet suffers from his feverish passion; both need to implore the gods, she for her health, he for the fire that threatens to consume him. El. 6 is about a failed meeting between the two. Galatea had asked to see the poet, but stormy weather had prevented the latter from leaving the house. He curses himself for his sluggishness, as this appointment could have been the start of a beautiful romance. In $\mathrm{el} .7$, the poet sings the praises of the beautiful eyes of Galatea, while expressing how bad he feels in his immense passion, and articulating his hopes for the future. In the next poem, the love-affair of a friend is discussed, and the benefits of love are sung; 'Relandus' draws a parallel between his friend and himself. El. $g$ is about Galatea's absence: the poet is overcome by feelings of jealousy when he imagines her to have a lover. $E l$. 10 actually takes the form of a letter addressed to the absent Galatea, in which the lover confesses that his life has been very gloomy since she has left. He would desperately like to know whether she still has any affection for him, or whether she has met another man. Even now, he hopes that she will return home soon, and begs her to write to him. El. 11 describes the poet desperately longing for Galatea while walking along the beach from where she has left the country, yet still looking forward to her return. In el. 12, the poet has left the country himself, seeking forgetfulness in a long voyage; but even abroad, Galatea fills his mind and heart. In the final elegy, we learn that Galatea has died in a storm. The poet is inconsolable; even after her death,

53 I do not understand on what grounds Guépin, Typisch Nederlands, p. 65, designates the cycle as the story of a happy love. 
he will remain devoted to Galatea, with whom he feels a perennial bound and to whom he dedicates his casti lusus (el. 13, 85-86).

The volume boasts an impressive number of stock themes and topics typical of the erotic elegy. Many of these have been identified in the annotated edition of Bosscha, who also listed them in his index rerum et verborum (pp. 117-121). A few examples may do here. The opposition between despicable riches and the blessings of love is one of these traditional themes ${ }^{54}$ often exploited by Reland (el. 3, 25-28; 8, 29-32; 10, 21-24 and the very elegant couplet of lines 39-40: 'Omnia nil in amore iuvant. Amor omnia praestat / solus, et innumeras exhibet unus opes'-'In love, everything else brings no joy, love alone offers everything and by itself supplies limitless riches'). ${ }^{55}$ Another topic develops the idea that lovers can hand over hidden messages to each other by talking with their eyes, touching the foot of the beloved girl, or writing words in wine or other liquids (see, e.g., Tibullus, 1, 2, 21-22; 1, 6, 19-20; Ovid, Amores, 1, 4; 2, 5): similarly, 'Relandus' is afraid that during her absence, a stranger will act in like manner in order to seduce her (el. 9, 7-24). Lovers carve the name of their mistress in the bark of a tree (see, e.g., Propertius, 1, 18, 19-22), and so does 'Relandus' (el. 10, 63-66). The mistress is quite often said to have musical talent (cf. Propertius, 1, 2, 26-27; Maximianus, 4, 11-12), ${ }^{56}$ and Galatea, too, is a musician $(e l .9,11-12)$. Disappointed lovers make a long trip to overcome their sorrow, and so does 'Relandus' (el. 12; cf. Propertius, 3, 21), etc.

Though playing with clichés, the poet succeeds in producing elegantly written variations on these traditional themes. Thus, to lovers who are waiting for their beloved, time passes excruciatingly slowly (cf. Propertius, 3, 20, 11-12; Ovid, Heroides, 11, 31); Reland intensifies this trope ${ }^{57}$ when he states that the sleepless nights of the lover longing to see his girl seem to last for ages ('centuries', he writes: el. 7, 15-16: 'Quodque tot insomnes (o quanta molestia!) noctes, / quas ego iuravi saecla fuisse, traham'-'and the fact that (how annoying!) I have to spend so many sleepless nights, nights that I could have sworn lasted for centuries'). Love poets often adduce the idea of inevitable death, and oppose the recurrent cycles of day and night or of the seasons to the straightforward span of human life. So too does Reland, when he has been missing Galatea for a year:

\footnotetext{
54 See, e.g., Tibullus, 1, 1; 3, 3; Propertius, 1, 14.

55 For this couplet, Reland, ed. Bosscha, p. 67 rightly refers to Secundus, el., 1, 2, 79-86; cf. especially l. 83 ('Omnia nil sine amore iuvant').

$5^{6}$ And hence also in Neo-Latin love poems: see, e.g., Veneres Blyenburgicae, pp. 295-300 (in Iohannes Iovianus Pontanus, Angelus Politianus, Paulus Melissus and others).

57 Just as the Neo-Latin poet Marcus Antonius Muretus (1526-1585) had done in his epigram 21, Ad Phyllidem, ll. 1-2: Cum ducenda mihi sine te sunt tempora, Phylli, / longior est anno mensis et hora die (cf. The Iuvenilia of Marc-Antoine Muret, ed. Summers, p. 82).
} 
'nature has returned to spring', he says, adding paradoxically: 'but this spring is for me an eternal winter, as she has not come back,,58 in these refined lines, marked by efficacious repetitions and wordplay, and addressed to the woods in which he and Galatea once took long walks together:

Ver licet acris hiems cultu spoliarit; ademtas

Reddit et ornatu ver meliore comas.

At mihi iam toto mea lux non redditur anno,

Ver rediit vobis, et mihi perstat hiems,

Iam reduces vestris Zephyri tepuere sub umbris,

Nostra tamen Zephyri vota referre negant.

el. $10,89-94$

('Though bitter winter has bereft spring of its splendid dress, a new spring brings the stripped foliage back, even with better ornaments. But the light of my life has not been brought back to me for an entire year now. For you, spring has returned; for me, winter goes on; the reappearing zephyrs grew warm in your shady places; but these zephyrs refuse to bring back the object of all my desires.')

Moreover, there are cases where our poet departs from classical topoi. Thus, as a soldier of love on duty for the sake of a girl, the lover would normally assure that he would do anything for his loved one, that he would even face heavy storms for her if necessary: 'ventos patiemur et imbres', Secundus (1, 3, 21) had written after e.g. Tibullus, 1, 2, 29-30; Propertius 2, 26, 35-44; Ovid, Amores, 2, 16, 19-30; Maximianus, 1, 35-36. 'Relandus', on the contrary, at the very point where he might hope that Galatea has some feelings for him (she has asked to have an appointment with him), is unable to visit her, for a sudden thundershower has frightened him and made it impossible to leave the house: later on, he blames himself for his cowardly behaviour (el. 6). ${ }^{59}$ Similarly, the brevity of youth is not used as an argument to enjoy the blessings of love for as long as possible (see, e.g., Catullus, 5; Tibullus, 1, 1, 69-74; Propertius, 2, 15, 23-24; also Secundus, 1, 5), but as a ground for rejecting these transient and unimportant joys of erotic passion (el. 2).

$5^{8}$ Perhaps also inspired by a short poem of Iulius Caesar Scaliger (1484-1558), quoted in Veneres Blyenburgicae, p. 39 o (line 3: ver aliis mihi tristis hyems).

59 This inversion of the traditional topos was a bit risky, since it might be interpreted as a sign of humour or of undermining the clichés of the erotic elegy. But to me nothing seems to point in that direction. 
When we try to assign a place to Reland's cycle in the Latin and Neo-Latin elegiac tradition, it is striking that every elegy is concerned with the beloved Galatea. If we look for an ancient example here, Propertius' first book of elegies, his Cynthia Monobiblos, which had been published separately by the poet, comes quite close to Reland, for almost all, but not all, of its more than twenty elegies deal with Cynthia. ${ }^{60}$ Remarkably enough, Propertius' booklet contained an elegy to a friend, who had just fallen under the spell of love (Prop. 1, 10): likewise, Reland has one elegy which deals with the recent love affair of a friend and only partially with Reland's beloved (el. 8).

Furthermore, Galatea recounts the story of a love affair in a logical and chronological order; it starts with the male lover's infatuation and ends with the death of the beloved. In this case, the model was, albeit in lyrical poetry, Catullus, who had written in a similar way in his poems 2 to 11 about his affair with Lesbia, an affair going from the first infatuation to the final rupture, due to the infidelity of the mistress. But here, some Neo-Latin examples have to be considered as well. The Italian poet Iohannes Antonius Campanus (Campano, 1429-1477), for instance, had written an encompassing and consistent love narrative in verse (about the mistress of another person, in fact). ${ }^{61}$ But Campanus' poetry did not enjoy the same popularity as that of Reland's compatriot Janus Secundus (1511-1536), ${ }^{62}$ one of whose extremely influential works, Julia Monobiblos, as it is often called, a book of elegies devoted to "Secundus" love for Julia, comes very close to Reland. ${ }^{63}$ Julia, too, recounts a love affair from the beginning until the end. The cycle starts with an account of how the poet was struck by the arrows of love (1); the lover then narrates an alleged episode from his youth, when the Muse predicted his eminent talents as a love poet (2); he then declares his ardent passion for Julia, whose life-long affection he implores

6o The first book of Ovid's Amores, too, mainly deals with one girl, Corinna, but there are additional 'poetological' elegies, and the nature of the love affair is substantially different from that depicted by Reland.

61 On Campanus, see, for instance, Beer, 'Ghostwriting in the Renaissance? Giannantonio Campano's Love Elegies for 'Diana', the mistress of Braccio Baglioni', pp. 41-65.

62 Though some of Campanus' poems can be read in Veneres Blyenburgicae, passim. For Secundus' influence in the Low Countries, see Van Dam, 'Second et la poésie néo-latine des Pays-Bas au XVI e siècle', pp. 169-184.

63 Earlier readers of Galatea seem to have been aware of the affinity of Secundus' and Reland's elegies, for they would not compare the latter to, say, Janus Dousa, Janus Lernutius, or Daniel Heinsius, famous Neo-Latin love poets from the Low Countries, while they would state that Reland came close to Secundus. Thus, in his Parnasus latinobelgicus, sive plerique e poëtis Belgii Latinis, a collection of epigrams eulogising the merits of Dutch and Belgian Neo-Latin poets, pp. 205-206 (ll. 5-6), Hoeufft claimed: 'Juliaque Hagano decus est paritura Secundo, / Relando pariet par Galatea decus'. 
(3); the next poem (4) describes a happy episode, where the lovers kiss each other; in poem 5 , the blessings and the banes of love are dealt with; the former prevail, and in a highly fervid and sensual poem the lover begs his mistress to give in to his passion while both lovers are still young; in poem 6 he declares his inability to capture the divine features of Julia in a sculpture; in the next elegy (7) a rival shows up, coming from another city, and desiring to marry Julia; the poet is jealous and violently curses the elderly rival; in poem 8 (perhaps one of the most powerful Neo-Latin poems ever written) the morning of Julia's wedding day breaks, heralding the end of the affair with the poet; the poet then (9) describes his distress, though he finds little solace in the arms of another girl. In the next elegy (10), the poet seems to reconquer Julia, but what he tells appears to be something he had dreamt of at night. In the final (11) elegy, the poet, aware of what he has achieved as a poet, begs that his sorrows over Julia may soon come to an end.

Reland's book, dealing exclusively with one beloved person, narrating the relationship the poet dreamt of from its start to its end, in a clearly chronological order, and incorporating, at the start and at the end of the volume, 'poetical' elegies in which the status of the reality of the affair is discussed, bears a strong resemblance to Julia, Secundus' first book of elegies. ${ }^{64}$ This, however, does not mean that the eleven elegies of Julia would be analogous to the thirteen poems of Galatea in every detail. Yet the overall structure is similar. Apart from the general concept of the volume, the radical and gloomy ends of both volumes catch the reader's eye: in Julia, the beloved has given in to the advances of a lover, who comes from another city ${ }^{65}$ and who will marry her; she thus leaves the city and is physically separated from her former lover. In Galatea, the girl might have left her homeland for a similar reason; she is thus inaccessible to 'Relandus'; eventually, she dies abroad. In both cases, the male lovers are left in deep sorrow. If they are deprived of their loved ones forever, ${ }^{66}$ the volumes of verse they have devoted to them will remain.

In his booklet Reland also created a number of elegies around motifs not found in Secundus, but taken elsewhere, from the ancient poets, it seems, or

64 For these aspects of book composition in Secundus, see Murgatroyd, The amatory elegies, pp. 10-14 and passim (in the excellent essays devoted to each elegy). Reland did not work with a central axis (which would be constituted by the seventh elegy), since this would mean some 288 lines for the first half, and some 414 for the second one. But there is a more positive (first) part of the elegies (el. 1-8, 370 lines), counterbalanced by a more plaintive one (el. 9-13, 414 lines).

65 Cf. Secundus, elegiae, 1, 7, 9; 1, 8, 7; 1, 9, 29. Secundus repeatedly uses the word 'peregrinus' for the rival.

66 For both, the girl is the first great love of their life (cf. also Propertius, 1, 1, 1). 
perhaps from some Neo-Latin imitators of the latter. The illness of Galatea in Reland, el. 5, might have its origin in Tibullus, 1, 5, 9-18 (sickness of Delia); 3, 10 (illness of Sulpicia); Propertius, 2, 28 (Cynthia is sick). Reland, however, turns the poem into a brilliant piece of ambiguous writing. Thus, the illness is styled as a state of heat, in such a way that it can also be applied to a state of amatory fervidness; the poet subsequently declares his own feverish ardour for Galatea, hoping that he might find relief. The message is clear: the poet hopes that Galatea will reciprocate his feelings, and that indulging in love will bring appeasement to the fevered condition of both.

When our Dutch poet writes that Galatea leaves the country by boat, this reminds us of Propertius 1, 8, where Cynthia is said to have the intention to sail away, or of Ovid, whose Corinna also travels over sea (Amores, 2, 11). And when Galatea dies at sea during a tempest, this is reminiscent of Propertius, 2, 26, where the Roman poet recounts a dream in which Cynthia is shipwrecked; and indeed, some singular elements in Reland's $e l .13$ are echoes of that dream of Propertius: Cynthia, while already floundering in the sea, calls out Propertius' name, and attention is paid to her hands coming out of the waves. Likewise, in Reland's el. 13, Galatea's hair gets loosened by the water, which also dirties her bosom; and she might have called 'Relandus" name (1. 31: 'et gemitu extremo mea nomina suspirabas' - 'and with your dying breath you whispered my name longingly').67

'Relandus' has Galatea summon him to come to a meeting-point on a given hour and day (el. 6): the poet must have had Propertius, 3,16 in the back of his mind, where the latter narrates that he has received a letter urging him to go to Cynthia's house at midnight; the resemblance goes further, since Propertius meditates about the dangers of nocturnal Rome and therefore hesitates a while to leave his home - and 'Relandus' eventually is frightened by a thunderstorm and therefore does not have the courage to go outdoors. ${ }^{68}$ Furthermore, the letter 'Relandus' addresses to Galatea in her absence might be a general echo of Ovid's Tristia or Heroides, but could also have been inspired by an elegy in the form of a heroid one finds in Propertius' elegies (4, 3, on married love, written by a Roman woman to her husband). Finally, the choice to let Galatea die might have been inspired by Propertius 4, 7 (where Cynthia is dead and buried,

67 In Neo-Latin poetry, the death of the mistress is a theme sung already before Reland, e.g., by Johannes Vulteius (Visagier, Voulté, c. 1505-1542): see, for instance the poems entitled Nuntium de morte suae Cliniae; Clinia mortua, optat mori; Se nullam, Clinia mortua, amare velle (quoted in Veneres Blyenburgicae, pp. $382-384 ; 384-385 ; 474-475$ ).

68 One also thinks of Ovid, Amores 1,11 (where a letter written by Ovid to invite Corinna, and handed over to Corinna's servant, who should give it to her mistress, is at stake) and 1, 12 (Corinna has written a letter to Ovid, declaring that she is unable to come). 
and appears to her former lover in a dream) - but a Neo-Latin source, such as Vulteius, whom we just mentioned, cannot be excluded. The central idea of Reland, el. 11, where the poet is standing in front of the sea, unfortunately unable to cross it so as to come closer to his loved one, seems to refer to Ovid, several of whose heroids centre around this theme. Yet there is an even more striking parallel in Ovid's Amores $(3,6)$, where the lover stands on the banks of a swollen river, incapable of reaching his mistress; the similarity with this elegy is remarkable indeed, since Ovid, just like Reland, has the lover express his desire to fly in the air and to cross the waters separating him from his girl. ${ }^{69}$

In a few cases it is a Neo-Latin model, rather than a classical one, that might have inspired the ideas and design of a poem of Reland, or might have functioned as an additional source of inspiration. Contrary to Bosscha, I do not think that the elegy on Galatea's eyes (el. 7) is indebted to a poem written by Janus Broukhusius (van Broekhuizen, $1649-1707$ ) on the eyes of Delia, ${ }^{70}$ for there are no verbal echoes of it in Reland. Cycles on the eyes of a loved one were popular during the Renaissance: one thinks of the cycle of Ocelli ( 42 poems!) written by Janus Lernutius (1545-1619) and published in Leiden in $1614^{71}$ But Reland's elegy about a friend who is in love $(e l .8)^{72}$ seems to owe something to another product of Broukhusius, an elegy written on exactly the same theme, Ad Cupidinem de amore Petri Francii. ${ }^{73}$ It should not come as a surprise that Reland liked to insert an echo of this in his own work, since Broukhusius' poem concerned Petrus Francius, Reland's teacher, and the dedicatee of Galatea. The opening of the poem in particular shows a certain similarity with Broukhusius' elegy: in both compositions, the friends are described as a new 'praeda' of Amor and Venus (Broukhusius, 1. 2; Reland, l. 4); both are said to have withstood the powers of Love for a long time, but now to have fallen under the spell of an overwhelming girl, and in both cases, 'uritur' is used repeatedly. ${ }^{74}$ Both poems stress the identity of the friends' feelings, reject intensive studies, and extoll the overwhelming joys of physical love. But there are also marked differences: Broukhusius owes much to Propertius, 1, 9 (also addressed to a friend who is in

69 Cf. Reland, el. 11, 41-44; Ovid, Amores, 3, 6, 13-14.

70 Jani Broukhusii Carmina, pp. 56-57: Ad Deliam de ejus oculis. The power of a girls' eyes is also sung by the elegists, e.g., Propertius, 1, 15, 33-42; Secundus, eleg., 2, 3 .

$71 \quad$ Iani Lernutii Initia, Basia, Ocelli \& alia poëmata (1614).

72 Cf. Reland, ed. Bosscha, ad locum.

73 Jani Broukhusii Carmina, pp. 53-55.

74 Cf. Broukhusius, ll. 5-8 ('Ille ferox, et adhuc nullis penetrabilis armis, / uritur; ac toto pectore vulnus alit. / Ille ferox, puerique timor cum matre volucris, / uritur. O Superi, non ego solus amo') with Reland, $e l .8,3-5$ ('Flectere millenae quem non potuere puellae, / uritur, et Paphiae fit nova praeda Deae. / Uritur, ac blandos intra se concipit ignes'). 
love), ${ }^{75}$ whereas Reland stays closer to the famous image of the triumph developed in Ovid's Amores, 1, 2, 23-52.

Another Galatea poem bears a noticeable resemblance to some verses in Daniel Heinsius' (1580-1655) Monobiblos, a collection of thirteen (!) love elegies for a girl named Rossa, issued for the first time in 1603 and reworked more than once by the Leiden professor. ${ }^{76}$

Especially the delicate ninth elegy of the original collection ${ }^{77}$ resembles Reland's $e l$. 6. In both cases, the girl proposes a rendezvous to the lover in a natural setting the next day; in both, the lover complains at length that the night before seems to last forever. Compare, for instance, Heinsius, 9, 1-2 ('Improba redde diem croceis Aurora capillis: / improba quin properas pergere? Redde diem') with Reland, el. 9, 13 and 17-18 ('longamque traho per taedia noctem; [...]/ Quae non cunctanti feci convicia Phoebo? Ingemui quoties "Invide, redde diem!'”- I spent a long night in utter distress. What aspersions did I not cast on Apollo's dawdling? How often did I lament: "You envious god, bring daylight back!'); and Heinsius' line 19 ('inter amoena vireta') with Reland's line 11 ('Nona suburbanis me cras dabit hora viretis' - 'Tomorrow at nine I will wait for you at the greensward outside the city'). The second parts of the poems, however, diverge: in Heinsius, we witness the two lovers together in the greensward, caressing one another, whereas 'Relandus' is struck by a storm ${ }^{78}$ and misses the rendezvous.

But let us return to the considerable influence Janus Secundus seems to have exerted upon Reland's volume. There are some other common features that deserve to be noticed here. First of all, similarities in vocabulary, images and iuncturae verborum were obviously an important means for Reland to voice his admiration for Secundus. These reminiscences are definitely present, albeit not profusely. Yet, no reader of Reland who came across a description of kisses would forget how powerfully and delicately Secundus had dwelt on them in his Basia and in his elegies. If that same reader came across such an extremely rare word as 'columbinus', he would immediately think of the even more rare word 'columbatim' used by Secundus (Secundus, 1, 5, 23: 'labra columbatim

75 Furthermore, the introduction of a friend in the cycle might owe something to Secundus' elegy 1, 9 (where the poet's friend Petrus Clericus comes in). In Reland's booklet, the circle of friends of the poet-lover is mentioned a few times.

76 Cf. Van Dam, 'Daniel Heinsius' Erstlingswerk'.

77 Heinsius removed this elegy from his Monobiblos after 16o6 (cf. Van Dam, 'Daniel Heinsius' Erstlingswerk', p. 194); it was, however, present in the 1603 and 1606 editions.

78 This storm might be a remote echo of the tempest in Secundus 1, 8, 11-20, or in Propertius, 1,17 . 
committe corallina labris'; Reland, el. 3, 20: 'blanda columbinis nexibus ora ligat'); ${ }^{79}$ so too would he think of Secundus upon seeing these kisses presented as dewdrops of the soul (Secundus, Basia, 4, 1-2: 'Non dat basia, dat Neaera nectar, / dat rores animae suaveolentes'; Reland, el. 3, 25: 'Fallor, et haec animi rores, non basia, dico' - 'No, I am wrong: these I should not call kisses, but dewdrops of the soul'), and he would consider Reland's words on Galatea, 'sola mihi fletus, solaque risus erit' ('she alone will cause me to weep, she alone to laugh', el. 4, 16) as an extremely happy echo of Secundus' 'unaque mi risus, unaque fletus erit' (Julia, 5, 2); he would also link the admittedly classical image of the enlacing of ivy and vine (el. 3, 21-22: 'Non secus ac stringi solet ambitiosa corymbis / pampinus'- Exactly as the embracing shoot of a vine usually binds itself tightly around clusters of ivy-berries') to some Secundan passages (such as Julia, 4, 21-22: 'Tunc ego lascivae potero contendere viti, / quae se vicinis implicat arboribus'; Basia, 2, 1-3).

Furthermore, the erotic elegy is given a modern touch by both poets: their elegies are not situated in Rome or on the shores of the Mediterranean, but in the poets' native countries. Quite a few references to contemporary reality can be found in Secundus, who, to give some examples, mentions Brussels and his native Mechelen (1, 9), and introduces a local custom from the Low Countries $(1,4)$ for which there is no parallel in antiquity. Reland, too, introduces the modern world into his poems. Instead of the Mediterranean, (a northern part of) the North Sea ('mare Caledonium') ${ }^{80}$ is mentioned in his elegies (el. 11, 43); ;1 and his homeland, the 'rura Batava' (el. 11, 56 ; cf. el. 12, 7; 12, 14; 12, 57; 13, $41 ; 13,46 ; 13,57$; cf. el. 4, 40), ${ }^{82}$ is touched on repeatedly. More conspicuously, our poet has a man and a woman drinking ... tea (el. 9, 19-20)!83 Admittedly, not only Secundus, but many Neo-Latin poets used to bring the ancient genre

79 Secundus, too, had used 'columbinis' (eleg., 2, 8, 10: 'labra columbinis roscida basiolis').

8o The denomination is rare in antiquity (Flaccus, Argonautica, 1, 8-9); one usually finds 'Britannicum mare', 'Oceanus Britannicus' and similar terms.

81 This concerns the place where Galatea was sailing to. Reland seems to have used 'Caledonium mare' meaning North Sea in general-thus not referring to Northern England-, as is clear from his poem 'Ad Nobilissimum atque suis Virtutibus \& Natalium splendore Illustrem Gulielmum Bentingium' [...], in Reland, ed. Perrenot, pp. ${ }^{48}-53$ (p. 48); see also his poem on the death of Fridericus Spanhemius [1701] (ibid., pp. 79-81, line 8).

82 The broad sandy beach ('immensae spectantur arenae') and immense surface of the sea of $e l .11,3$, too, accord with a Dutch landscape.

83 For tea (and coffee) in Neo-Latin poetry, see, e.g., Yasmin A. Haskell, Loyola's Bees. Ideology and Industry in Jesuit Latin Didactic Poetry (Oxford: Oxford University Press, 2003), pp. 299-302 and passim. 
to their own times: they did not want to give the impression that they were writing timeless, insensitive exercises, formal imitations of ancient models.

Similarly, modern manners and morals have entered Secundus' and Reland's poetry cycles. After all, ancient lovers, as depicted in the erotic elegy, had no qualms about airing their homo-erotic love feelings (see, for instance, Tibullus' elegies for Marathus); they could admit to loving two girls at the same time (see, for instance, Ovid, Amores, 2, 10), ${ }^{84}$ or confess that they cheated on their mistresses while having affairs with the latter's servants; ${ }^{85}$ nor were they deterred by the fact that their loved one was a married woman. Sexual morals, too, were depicted differently. Intercourse could occur in the darkness of public space; a lover would boast of his physical strength and tell how he had 'satisfied' his mistress, say, five times consecutively (Prop. 2, 22; Ovid, Amores, 3, 7), or would go into some detail while recalling a night in the bed of the beloved (Prop. 2, 15), but he could also admit to being temporarily impotent (Ovid, Amores, 3, 7; Maximianus, 5), and would depict himself now and again as a drunk (Propertius, 1, 3; 2, 29). In the Neo-Latin elegies of Secundus and Reland, ${ }^{86}$ one notices how themes like the aforementioned are less prominently present, are at the most hinted at, or are even completely absent. Though these modern poets take over a great deal of themes and topics from their ancient examples, depict the passion of love in fervid poems, and defend the licentiousness of their poetry by referring implicitly or explicitly to the ancient genre they are necessarily imitating, one witnesses in their poems a restraint that is more in line with the behaviour and the morality of the Modern Era. It may be enough to observe that in Secundus' booklet, the affair of Julia with her poet-lover comes to an irreversible end when the girl marries another man, whereas the presence of a husband would not be an obstacle for a love affair in classical poetry (e.g., Tibullus' Delia had a husband [see, for instance, 1, 2 and 1,6]). ${ }^{87}$ In Reland's work, the poet's yearning for an

84 Also in humanist Neo-Latin poetry; see, for instance, an elegy, entitled De varietate amorum, written by Ludovius Ariosteus (Ariosto, 1474-1533): Ariosto, Poesie latine, pp. 56-63; or Hercules Strozza's (Strozzi, 1471-1508) poem Quod duas pariter amet, quoted in Veneres Blyenburgicae, p. 504.

85 In Propertius, 4, 8, 'Propertius' was having sex with two women when he was caught by Cynthia. In Ovid, Amores, 2, 8, the poet had an affair with her servant Cypassis, which was discovered by Corinna.

86 As in those of his contemporaries and of his preceptors, but not in, for instance, those of Neo-Latin poets of early Italian humanism.

87 Reland seems to move in that direction as well. Following the elegiac tradition, he desires a lasting, lifelong relationship with Galatea (e.g., el. 3, 31-32). But does he not allude to the bond of marriage (which is absent from ancient amatory elegy), not only when he describes Galatea as the person with whom all his former ardours and the unrest of his 
affair of the heart with Galatea breaks off with the death of the beloved. Our poet at times supposes that he might have a rival and imagines Galatea with another man, but nothing in the girl's behaviour indicates that she is really seeing another man (she dies as a virgin: 'Et non libata virginitate cadis', el. 13, 20); and even while he supposes for a moment that she has a lover now, he cannot heap reproaches on her, which is contrary to the ancient elegists, but in accordance with Secundus. ${ }^{88}$ The lover and poet himself, once he is burning with desire for Galatea, does not indulge in other liaisons, ${ }^{89}$ with one exception: when he is desperate about Galatea, who has been absent for a year, he tries to find solace in a journey abroad (a classical motif in the erotic elegy), ${ }^{90}$ where he is captivated, for a short while, by a girl who bears a remarkable physical resemblance to Galatea (el. 12, 33-56) - this motif of trying to find a kind of alter ego of the beloved, who still fills the heart of the disillusioned lover, might have been taken from an elegy of Petrus Lotichius $(2,9)$, as Bosscha ( $a \mathrm{~d}$ loc.) suggested. In comparison with Secundus, then, Reland displays even greater self-restraint, and exhibits behaviour at which the respectable bourgeois could hardly take any offence. Galatea has nothing in common with the capricious or lascivious, frivolous, hetaera-like figures of the ancient erotic elegy; and in comparison with Secundus' Julia, she comes across as a well-behaved girl whose beauty has not at all gone to her head; she would not indulge in such frivolous play as Julia in Secundus 1, 4; she would not try to seduce by promising kisses and 'what comes after those kisses'; she would not ask to be sculpted as Julia did in Secundus, 1, 6; she is chaste and virtuous; there is no allusion to her having made love to any man. The lover, too, is well aware of the dangers of passionate affairs, and explicitly condemns these, as we saw (el. 1; 2; 3). He stresses the brevity of beauty and youth, which does not incite him to savour the joys of life and love while it is still possible (as the ancient elegists did), but makes him say no to lustful love. When he describes the physical attractiveness of Galatea, he focuses on her hair, eyes, forehead, arms, cheeks, gait ... He does not praise more intimate bodily parts of the beloved; only once does he

blood have come to an end (el. 4, 14-15: 'Galatea favillis / imposuit frenum sola modumque meis'), but also when he mentions that his readers would say 'Carmine quae toties cecinit, sensisse merebat / gaudia, legitimi deliciasque tori' (el. 3, 43-44, my italics)? In this context one should perhaps not forget that (contrary to Secundus), 'Relandus' makes no opening towards a new affair (el. 13). Desiring a lawful marriage is a theme occurring in Neo-Latin love poetry: see, e.g., the poem Imaginarium Rosinae coniugium, written by Paulus Melissus Schedius (1539-16o2) and quoted in Veneres Blyenburgicae, pp. 436-438. Cf. Murgatroyd, The amatory elegies, p. 122.

89 Nor did he indulge to these in the past, as his 'bona mens' always took control over of things (e.g., el. 1, 7-10; 2, 13-22) — this distinguishes him from, e.g., Propertius, 2, 22. 
mention the bosom and bra of his mistress. ${ }^{91}$ When he imagines how he would like to rest in Galatea's arms, he makes use of innocent and decorous expressions, and offers a so to speak 'softer' version of what Propertius and Secundus had committed to paper: 'Relandus' would kiss the eyes of his beloved, while she feels sleepy; when she would push him off, he would kiss her hand, lay it on his chest, and then kiss her again: the intimacy of love-play would not go beyond that first stage $(e l .7,31-48) \cdot{ }^{92}$ Similarly, there is much more moderation in Reland than there was in Secundus when it comes to execrating a possible love rival. In Secundus $(1,7)$ the jealous narrator hopes that the rival will die in an accident, that the wheels of a carriage will crush him, that his body will be torn apart by birds, or else, that his relation with Julia will be disastrously unhappy, that Julia will become utterly disgusted by the rival's ugly face, and that he will be too exhausted to make love with her, etc. ${ }^{93}$ In Reland (in the charming el. 9), on the contrary, nothing of the sort is found; the young poet limits himself to a rather innocent tirade against the rival: 'Do not touch my sweetheart, for you will rush to perdition, and the gods will take revenge; you villain, stop trying to seduce Galatea!' (el. 9, 39-42). For the rest, the poet, while dwelling on the techniques this other man might use to impress the girl, takes many an idea from the ancient love poets (Tibullus and Ovid in particular)thus, this other man will go out for a walk with Galatea, will make hidden signs with his fingers when he hands her a cup, or will give her messages with his looks and eyebrows when they are seated at the table; here too, we witness a seventeenth-century gentleman-like behaviour on the part of the man: he will offer Galatea a cup of tea, and will invite the girl to accompany him to the roof of the house, so as to look at the star-spangled sky; on the stairs, when the girl threatens to stumble, he will give her a hand, allowing him to touch her etc. (el. 9, 14-15, 19-24, 31-39; cf. e.g., Tibullus, 1, 6, 25-26).

Both in the classical and in the Neo-Latin erotic elegy, the lover's poems devoted to his love-affair play an important role. These poems might help to conquer her (cf., e.g., Tibullus, 2, 4, 19; Ovid, Amores, 2, 1, 33-34); they also immortalise the relationship as well as confer a lasting fame on both the

91 Actually not of Galatea, but of Rhodope (in el. 12, 44). And even then, Reland toned down his verse: in the first edition, we read 'Et strophio turget vincta papilla pari'; from the second edition on, this has become 'Et premitur strophio vincta papilla pari'. A bra was also mentioned by Secundus $(1,5,71)$. In Reland's couplet, the bra and a kind of shoulder band are mentioned together: this is a reminiscence of Ovid, Ars amatoria, 3, 273-274. Confront this with, e.g. Maximianus, 5, 33-36.

92 Therefore, no bites given in the neck of the loved one, or marks of the nails, as in Maximianus, 3, 69, or in Tibullus 1, 8, 37-38.

93 In Secundus' ninth elegy (1. 49) he is even called a barbarian ('barbarus'). 
poet-lover and the beloved (cf., e.g., Propertius, 3, 1, 35; 3, 2). In like manner, Reland says about Galatea 'aeternumque meis vivet celebrata Camenis ('and she will live forever, celebrated by my muses', el. 4, 17) and 'Per te fama meis constabit sola Camenis' ('Fame will only come to my muses' products by your grace, Galatea', el. 8, 31).

The fact, then, that the divine beauty of the beloved is being praised time and again in both Secundus and Reland is not relevant: these are books of love poems, and in the traditional erotic elegy references to the attractiveness of the adored are ubiquitous. ${ }^{94}$ Nor does the mix of elements coming from different ancient (and Neo-Latin) models, linking Secundus to Reland, offer proof of Reland's dependence on his older compatriot: he has this in common with almost all Neo-Latin love poets. As in Secundus, we find passages and poems in Reland that remind us more of the passionate style of Propertius, other ones that call to mind the softer melancholy of Tibullus, and still other ones where the rhetorical lightness of Ovid is at work; the ludicrous or comic side of Ovid, however, is absent: a poem on the death of the girl's parrot (Ovid, Amores, 2, 6) is unthinkable in Galatea; and Ovid's licence of content, as we said, is almost completely absent from Reland, who primarily imitates the Roman poet's elegant, smooth, light verse and his rhetorical creativity. To give a few examples: as far as the setting of the poems is concerned, it seems to me that Tibullus ${ }^{95}$ is very present in Galatea, though the latter's loci amoeni also figure in Secundus' Basia and Elegiae. Reland's elegies are almost exclusively situated in nature, not in a city. ${ }^{96}$ Quite often do we read about the seashore, but even more often about parks and woods located, it seems, on the outskirts of a city (but the environment is a natural one, not, as in Tibullus, a rustic one: no farms, no domestic animals appear in Reland). This is the Tibullan setting of a life of simple happiness; likewise, the bond of affection 'Relandus' dreams of comes close to what Tibullus often depicts: $e . g$. walking with his mistress in an entirely natural landscape, holding her hand, kissing her, lying down with her on the fresh grass (cf., for instance, Tibullus, 1, 2, 73-74), in short, spending simple, but harmonious days with her for the rest of his life. ${ }^{97}$ Ovid's rhetorical cleverness

94 Cf. Murgatroyd, The amatory elegies, p. 10.

95 Some other features also recall Tibullus. Thus, Tibullus 2, 5, 109 ('iaceo cum saucius annum') declares that he has been unhappy in his love for a year, which is echoed in 'Relandus" complaints about Galatea, who has been absent for a year (el. 10, 91: 'At mihi iam toto mea lux non redditur anno').

96 Tibullus' setting is quite constantly natural, whereas in Propertius rustic environments and urban settings alternate; Ovid rather depicts life in the city.

97 It is possible that Reland was influenced here by the long-established success of such works as Constantijn Huygens' Hofwijck (1653). In his funeral oration, Serrurier stresses 
and elegant way of expressing things appear time and again in Reland's verse. When the lover has missed a rendezvous with his friend and feels guilty for this, he conjures her to forgive him; he admits not to deserve her forgiveness; but she will pardon him, for her lenient nature forces her to do so and her clemency is as intense as her beauty (el. 6, 63-68: 'Da veniam, Galatea, meae, mitissima, culpae, / nec rigido fultum cor adamante gere. / Munera, si crimen spectes, indebita posco. / Conveniunt formae sed tamen illa tuae. / Ex oculis invita tuis clementia spirat, / quam nisi tu dederis, se dabit ipsa mihi'. 'Gentle Galatea, please forgive my error, do not display a heart bolstered by inflexible steel. If you consider my crime, I do not the deserve the favours I am asking for, but they are nevertheless in harmony with your beauty. Willy-nilly, your eyes exhale a clemency which, if not shown by you yourself, will offer itself it me'). Playing with an Ovidian example (Amores, 1, 2), the love-struck poet confesses that he has lost his 'bona mens', his 'sapientia', but then proceeds to a typically Ovidian paradox, employing the typical iterations and variations of the Roman poet: in point of fact, 'Mens bona' has not left 'Relandus', it is the mind itself which forces him to love her, for it would be stupid not to fall in love with such a beauty (el. 2, 9-11 and 23-30): 'Mens bona, praecipites animi compescere motus / docta, repentino tacta stupore silet. / Non silet haec; fallor; quae sola necare favillas / ante meas potuit, suscitat ipsa meas./ [...] Nunc bona mens mirata tuam, pulcherrima, formam; / ipsa mihi dicit; quam sapienter amas! / Legitimo, qui te cepit, da frena calori. / Cedo, nec indignor, legibus ipsa meis./ Te quoties monui, ne quo capereris amore. / Haec animum teneat, non nego, forma tuum. / Qui videt hanc, nulloque animum depascitur igne, / ille bonae mentis nil habet, ille stupet'-—My good discernment, trained to repress the rash passions of my heart, is suddenly stupefied and dumbstruck. No, not dumbstruck, I am mistaken: that discernment, which at one time could only supress the seeds of my passion, is now invigorating them. Now my good discernment itself, while admiring your beauty, o fairest Galatea, tells me: 'How wise are you in love! Give free rein to the right passion that has taken control of you. Without indignation do I here yield to my own rules. How often have I warned you not to let yourself be carried away by just any love! But this beauty may possess your heart: I do not object! Whoever's heart is not devoured by the fire of love upon seeing this girl, is utterly bereft of good discernment, and is utterly insensible!").98

the fact that Reland was fond of nature, but this idea might have been taken from the elegies themselves, since Serrurier's expressions recall some of Reland's verses (Serrurier in Reland, ed. Bosscha, p. 18).

The idea behind this is in itself a topos of love poetry. 
Mythological examples and parallels abound, and recall both Propertius and Ovid. Reland's plain style, which is never obscure, and the natural sequence of thoughts, images and ideas, which does not manifest the at times abrupt and puzzling transitions characterising Propertius, can be labelled as Ovidian. Though many of Reland's ideas and themes can be linked to Propertius, as we noticed here and there, ${ }^{99}$ his elegies are markedly distinct from the furor of the Umbrian poet.

Finally, some substantial differences between Secundus and Reland appear, it seems to me, if one considers the general concepts of their amatory booklets.

Obviously, the situation of Reland is different from that of Secundus. Towards the end of Secundus' Julia Monobiblos, one feels that the poet-like many of his predecessors in the genre of erotic elegy - is trying to cope with the loss of Julia, is gradually coming to terms with his sorrow, and is in a fit mental state to experience new affairs. ${ }^{100}$ For Reland, there will come no new affairs, there will come no new love poems. Thus he can consistently depict Galatea as the unique love of his life, and declare that he will worship and love her for the rest of his life (el. 13, 85-88). His love dreams have resulted in both a lifelong veneration for, and intimate solidarity with, the beloved, and ... a volume of casti lusus (el. 13, 85-86).

This brings us to the 'status' of the girl Galatea. As far as ancient erotic elegies are concerned, it is hard to say whether or not a real person stood behind Gallus' beloved Lycoris, Propertius' Cynthia, Tibullus' Delia or Ovid's Corinna; it is particularly difficult to assume that Ovid's mistress was a real person; and it is far from easy to put together all the facts and pieces of information Propertius provides about Cynthia into a single and consistent biography of the poet's mistress. Anyway, before the Romantic movement came into being, the possible gap between Dichtung and Wahrheit was a minor issue; readers were aware of the fact that the ancient genre presupposed that through the development of a number of stereotyped commonplaces, varied with literary inventiveness and craftsmanship, a romance was described, whether it had existed or not; even if it had existed, it had to be adapted to the template of

99 Another point of resemblance, perhaps explicitly sought after by Reland, is the fact that 'Relandus' presents himself as a person who had been able to avoid the temptations of love before he had met Galatea, whereas another elegy says (el. 4, 9-12) that he has been in love before, even more than once. Similarly, Propertius presented Cynthia as his first love $(1,1,1)$, yet in $3,15,3-8$ speaks about a certain Lycinna with whom he had been in love in his youth. In both cases, the inconsistency can be explained by the fact that these early affairs were nothing compared to the great loves (Cynthia, Galatea) of their lives (Propertius, 3, 15, 9-10; Reland, el. 4, 11-16). 
the love elegy. ${ }^{101}$ This holds true for Neo-Latin love poetry as well. Often poets would remain ambiguous about the reality of the romance they had sung. Janus Secundus (1511-1536), for instance, equivocated on the reality of his love affair with Julia, so passionately sung in his homonymous first book of elegies. ${ }^{102}$ In Latin and Neo-Latin love elegy the ambiguity at issue would to some extent arise from the fact that the poets liked to endow their own persona as a lover with some particulars tying in with their own biographies. Reland, too, as we saw, continued to present himself as the former lover of Galatea in an isolated poem that was not part of his Galatea cycle and that was written at the time or somewhat later.

In a way, Reland was building on Ovid, the fictitious character of whose Corinna emerges from the first elegies on: there, it is said that the poet was a love poet before he loved; that he was in love before he had a person to love; Cupid had hit him, but he still lacked a beloved girl (Amores, 1, 1; 1, 2): in the eyes of the reader such a course of action adds a lot of doubts about the reality of Corinna. Reland, then, takes this a step further and makes the love-affair even more problematical. He presents Galatea as a girl he actually knew, but with whom he had never lived through a passionate affair. He was on friendly terms with her, but had never given her any sign of his desire. The booklet starts from the idea-which looks modern to me-that if the poet were to confess his feelings of amorousness for her, he might even destroy the existing friendship, a risk he does not want to take. For Galatea, too, whose relationship with 'Relandus' is strictly platonic, is a person who feels revulsion at passionate affairs, who would laugh at his confession (el. 1, 33-34), and perhaps would not even allow him to see her if he declared his love:

At tibi si prodam; quid enim nisi prodere sperem?

Dicar amicitiae ius violasse tuae.

Quae Venerem, quae tela Dei narrata cachinno

Excipis, ardores num paterere meos?

Laesa novo dices convicia mille calori.

Forsan et a facie cogar abesse tua.

$$
\text { el. 1, } 31-36
$$

('But suppose that I disclose my feelings to you (is there indeed anything I would rather do?): you will say that I have broken the laws of our friendship. When Venus is mentioned, when I speak to you about Cupid's arrows, you burst

101 For the Roman amatory elegy, see, e.g., Holzberg, Die römische Liebeselegie.

102 Cf. Gelderblom, Secundus'versies, p. 52. 
into laughter; therefore, you would not tolerate the heat of my passion, would you? Offended, you will execrate with dozens of curses that strange, new heat of passion; and, perhaps, you will even forbid me to see you.')

Hence, the poet decides to utter his feelings of love in his private poems only, in which he would describe the fire that devours him. These poems would not be read by the girl-in this case, contrary to what normally happens in erotic elegy, poetry is not a means to conquer a girl. There is no coup de foudre here, as there is in Propertius or in Secundus, but a passion that arose from a relation of friendship. The beloved remains unaware of this passion. ${ }^{103}$ The poet describes a romance that is a fiction in the real world. He is constrained to express his eternal longing for Galatea, with whom he has never had an intimate relationship. ${ }^{104} \mathrm{He}$ can only desire the girl or imagine what an affair with her would be like. Thus he inevitably is, as he says in the first elegy (el. 1, 53-54), a figure like Tantalus, who stands in the water, yet cannot drink from it. ${ }^{105}$ The fire of his internal passion is a secret. ${ }^{106}$ When Galatea dies, she dies a virgin; love has not been consummated (el. 13, 20 and 85-86). "Relandus" concealed passion is not even known to his friends. ${ }^{107}$ The latter do notice that 'Relandus' has changed, but ignore what is going on. When they discover a booklet with the title 'Galatea' they realise he is in love, and would like to know who the beloved is (this alludes to a topos in erotic poetry, compare, e.g., Catullus, 6 ), but they cannot guess who is hiding behind the pseudonym, nor are they informed about her identity.

At first thought, the poet's decision to explicitly admit that the depicted romance never occurred in real life might threaten to enfeeble the reader's interest in the story. ${ }^{108}$ It looks like an unusual and ambiguous renuntiatio

103 To some extent, this is comparable to the secret love for Candida the poet Maximianus describes in his fourth elegy.

104 Cf. el. 3, 33-36 ('Hei mihi! Quod grata fingantur imagine forsan / non eventuri, gaudia vana, dies! / Forsitan haec cupidae tantum vaga somnia mentis / materiem numeris Di voluere meis.'). See also Reland, ed. Bosscha, ad locum, where a parallel to an elegy of Sannazarius is suggested (Jacobi Sannazarii Opera omnia, Elegiae, I, 1, p. 87: 'Sed quid ego, hei misero, ventosus inania fingo / somnia, quae forsan non feret ulla dies?).

105 Obviously this situation reminds us of Petrarch's Canzoniere, the more so because Galatea lays down her life, just as Petrarch's Laura.

106 Cf. el. 1, 31-35, 55-56; 5, 31-32; 12, 11-14 (the poet has left his country to find relief for his sorrow, and says: 'Et tandem peregrina sinu me terra recepit, / quam patriae possem praeposuisse meae, / una nisi arcano sibi me iunxisset amore, / et faceret Batavum dulcius esse solum').

107 Cf. el. 10, 53-56 (1. 56: 'O soli tantum flamma scienda mihi!').

108 In his circle (friends, family, educators, colleagues), the young author may have desired to benefit from the open declaration that this was a mere product of literary fiction, a mere lusus, and not the literary transformation of a real passionate affair with a girl. 
amoris or refusal of love. Yet, it seems to me that this presentation has no major disadvantages. The classical components of a love story can be worked out in this situation as well, insofar as the author assumes the role of a secret lover, who gives a voice to his aspirations, dreams and fears: thus he can make use of all the topoi of erotic elegy. Moreover, presenting Galatea as an actual friend of the poet involves yet another level of ambiguity and literary play, introducing another dimension. Indeed, at times the reader asks himself if an episode only applies to Galatea as an imaginary mistress, or also to Galatea as 'Relandus" girl-friend, as she is presented by the poet. When (in elegy 5) we read that Galatea is ill and that both she and 'Relandus' have tried a variety of remedies, the presence of the young man at Galatea's sickbed is understandable insofar as the secret lover already is a friend of the girl. When (in el. 6) Galatea informs 'Relandus' that she wants to see him, but does not say why, one wonders if she is acting as a friend in some kind of trouble or if she is acting as the longed-for mistress, and whether the poet is hoping that she, too, has begun to have more than only friendly feelings for her comrade. This is an important aspect as well: as a comrade of Galatea, 'Relandus' can hope that, in time, and even though he does not declare how much he is in love with her, the girl, too, will start to have more intimate feelings for him. Hence a spark of hope is present in the first part of the elegies, as at the end of $e l .5$ and at the start of $e l .6$; but it gradually fades away afterwards, ${ }^{109}$ after Galatea's departure. ${ }^{110}$ Fundamentally, the love story is presented as a fiction or as a desire; it is based upon an allegedly true bond of friendship, which might be a fiction as well.

The second difference is closely connected to the first: Secundus presents himself as a person made for love from his early childhood $(1,2)$, whereas 'Relandus' is a person who, though attracted to girls (el. 4, 9-10), has always objected to the passions of love, as we said before, and has hitherto managed to turn a blind eye to the temptations of love and to avoid gazing at girls whose beauty strikes (or might strike) him. Yet on the other hand, Reland does not display that same intense confidence in his own talents and in his abilities as an elegiac poet as Secundus had expressed in 1, 2 and 1, 11. Admittedly, there are some stock references to the value of his poems (el. 4, 17-18: 'aeternumque meis vivet [Galatea] celebrata Camenis, / si faveant numeris fata benigna meis'-'and she will live forever, celebrated by my muses, if at least fate propitiously favours my verses'; 8, 33-34: 'Per te [o Galatea] fama meis constabit

\footnotetext{
109 Though it never dies completely in elegies 1-12; cf. el. 10, 1-4; 69; 107-122; 11, 69; 12, 61: 'Fallor? An hinc vires animus capit?').

110 Cf. supra, note 64. The cycle's evolution from (moderately) positive (i.e. hopeful) to negative (i.e. despairing) is often present in the (ancient and Neo-Latin) amatory elegy, as is the case in Secundus' Julia.
} 
sola Camenis, / solus et a vestro nomine surget honos'-'Fame will only come to my muses by your grace, o Galatea, and only the product of my muses will grant me respect'), but he does not go so far as to write that a god has predicted his talents as a lover and a love poet when he was a boy (Secundus, Julia, 1, 2).

In this introduction to Galatea it is not possible to present a detailed discussion of the dispositio or structure of Reland's volume. Since the elegies follow the logical and chronological order of a fictitious affair from its start until its ending, no artifice was needed to secure the unity of the volume. As in Ovid and in Janus Secundus, the first three elegies contain material that can be called prefatory, as Reland's dreamt-of affaire has not started yet. ${ }^{111}$ The final elegy contains some references to the first one. From the fourth elegy on, we encounter a number of situations the lover is confronted with; they follow a natural order, though one would have expected the seventh elegy (on the beautiful eyes of Galatea) to have come earlier. The poet secured the unity of the volume by repeating a fair number of themes, ideas and images in different poems; he also had an eye for smooth transitions: thus $e l .6$ (on the failed rendezvous) ends with a reference to the eyes of Galatea (1. 67 , 'oculis'), while the next poems deals with the eyes (l. 1, 'oculi') of the loved one. The ambiguity of $e l .6$ (on the illness of Galatea, and the feverishness of 'Relandus') is well prepared in el. 3, 15-16: 'Reliquis herbae medeantur, amantis / cura tamen medicam respuit una manum'-let other men be healed by herbs; only the cure of a lover rejects a doctor's helping hand'; cf. 6, 15: 'Auxilium medicina negat; tentavimus artem'-'Medicine refuses help; we have tried that art'). Particularly from $e l .9$ on, the poems constitute a strong unity: in $e l .9$, the poet laments Galatea's absence; in $e l .10$, we are told that she has actually sailed away over the sea; in $e l$. 11, the poet dreams about following Galatea abroad and leaving his country, which does not mean anything to him when Galatea is not there; in $e l$. 12, the lover has sailed off, but longs for his homeland, where so many things remind him of Galatea; in el. 13, it appears that Galatea has died in a storm at sea. In $e l .10,95^{-96}$, the possibility of such an end was already hinted at ('Deseruit patrios temeraria nympha Penates, / ausa procelloso credere vela noto'-'Audaciously, the girl has left her country's gods when she dared to entrust her sails to the stormy south wind'; 'procellosus' and 'Notus' are repeated in 13, 41-42: 'Hei mihi, cur Batavo deducta est littore puppis, / illa procellosis praeda futura Notis'-'Ah me! Why was that ship launched from Holland's shores, bound to fall prey to the stormy south winds?'). ${ }^{112}$ Similar

\footnotetext{
111 Cf. Murgatroyd, The Amatory Elegies, p. 104. In Ovid, Secundus and Reland, the amorousness is already declared in these prefatory elegies. Contrary to Ovid and Secundus, Reland already mentions the name of the girl (and his love for her) in the first elegy.

112 Cf. also el. 11, 65-68; and 13, 25-36.
} 
repetitions could also provide smooth transitions from one poem to another. Finally, some 'auto-referential' sections enhance the coherence of the booklet. Thus, in $e l .13,39-40$, when talking about the woods and greens where Galatea used to walk, Reland writes: 'Vos ego, dum vestris Galatea errabat in umbris, / dixi Thessalicis anteferenda iugis' ('As long as Galatea was walking in your shady greens, I said that you deserved to be placed before Thessaly's high lands'), referring to 10, 105 ('Vobis Pausilypus cedent, et Thessala Tempe''Posilipo and Thessaly's Tempe valley must give way to you'). Similarly, the story of Leander, who crossed the Hellespont every night to meet his beloved Hero, comes up twice: el. 11, 61-62 (Nuper [...] canebam / Leandri querulis tristia fata modis'-'A while ago in plaintive tones I sang of Leander's sad fate'), referring to $6,41-42 .{ }^{113}$

Adriaan Reland displays remarkable skill in creating a coherent love affair, which is a story of continuous yearning and of unfulfilled desires. His volume demonstrates an admirable linguistic and metrical command of Latin; his literacy and erudition allow him to successfully tread the beaten paths of erotic elegy. He produces poems written in a uniform and refined style, which owes much to the smooth sophistication of Ovid, and succeeds in proposing some lines that can measure up to the models he imitates. Though he does not move the reader with pungent images the way Janus Secundus had done, and his elegies are perhaps enervated by a degree of monotony, he has his merits as a late representative of an old genre: even for a reader of today, poring over Galatea is a pleasurable experience. ${ }^{114}$

\section{Bibliography}

\section{Sources}

'Article XV. Eloge de M. Adrien Reland, nouvellement mort Professeur ...', in S. Masson et al. (eds), Histoire critique de la Republique des Lettres tant ancienne que moderne, vol. 15, Amsterdam, 1718, pp. 412-446.

Ariosto, L., Poesie latine, ed. Aldo Capasso, Florence, Fussi, 1947.

Broukhusius, J., Carmina, Utrecht, François Halma, 1684.

\footnotetext{
113 Yet, the reference is not entirely correct. Relandus says in $e l$. 11 that he has deplored the sad fate of Leander earlier on, but that he should have praised Leander's happiness, as Leander was able to swim to his beloved. In el. 6, however, it is not Leander's ill-fated end that is dealt with, but his promptness and audacity to swim over the Hellespont.

114 I want to thank my colleague Nicholas De Sutter, who corrected my English.
} 
Bruno, H., Mengel-Moes, van verscheyde gedichten, op allerhande voor-vallende saecken begreepen / Varia diversi generis \& argumenti poëmata, Leiden, Salomon Wagenaer, 1666.

Blyenburgh, D. van, Veneres Blyenburgicae, sive amorum hortus: in quinque areolas divisus ..., opera Damasi Blyenburgi Batavi, Dordrecht, Isaac Caninus, 1600.

Burmannus, C., Traiectum eruditum, virorum doctrina illustrium, qui in urbe Traiecto, et regione Traiectensi nati sunt, sive ibi habitarunt: vitas, fata [et] scripta exhibens, Utrecht, Jurrianus van Paddenburg, 1738; Utrecht, Besseling, 1750.

Catulli, Tibulli, Propertii nova editio, ed. J. Scaliger, Paris, Mamertus Patissonius and Robertus Stephanus, 1577 .

Catulli Tibulli Propertii Opera, ed. U. Gahagan, London, J. Brindley, 1749.

Carus, L.T., De werken van T. Lucretius Carus van het heelal. Uit het Latyn in het Nederlandsch vertaald, tr. J. de Witt, Amsterdam, Petzold, 1701.

C. Valeri Flacci, Argonauticon libri octo, recensuit E. Courtney, Leipzig, B.G. Teubner Verlagsgesellschaft, 1970.

Higt, E.W. Gedichten van Ernst Willem Higt, ed. A. IJpeij, Harderwijk, E. Tijhoff, 1803.

Hoeufft, J.H., Parnasus Latino-Belgicus, sive plerique e poëtis Belgii Latinis, epigrammate atque adnotatione illustrati, Amsterdam and Breda, Peter den Hengst and Willem van Bergen, 1819 .

Huygens, C., Vitaulium. Hofwyck hofstede van den Heere van Zuylichem onder Voorburgh, The Hague, A. Vlacq, 1653 .

'Imitation de la XII. Élégie latine d'Adrien Reland, sur la mort de Galatée', in A. Ferrand (ed.), Pièces libres de M. Ferrand, et poësies de quelques autres auteurs sur divers sujets, London, Godwin Harald, 1738, pp. 95-102.

Jordensius, G.D., Gellia, lusus poeticus. Accedunt ejusdem Eclogae et Epigrammata. Leiden, Le Mair, 1763 .

Lernutius, J., Initia, Basia, Ocelli, \& alia poëmata, Leiden, Lodewijk Elzevier, 1614.

Kampen, N.G. van, Beknopte geschiedenis der letteren en wetenschappen in de Nederlanden (...), vol. 1, The Hague, Weduwe J. Allart, 1821; vol. 3, Delft, eadem, 1826.

Kooten, T. van, 'In Reginam cultissimis versibus ab Johanne Adamo Nodell celebratam', in J.A. Nodell, Regina, lusus poëticus. Elegiae XIII. Adcedunt ejusdem varii generis carmina juvenilia, Franeker, Dionysius Romar, 1775 , fol. * $3{ }^{r}-{ }^{*} 4 \mathrm{v}$.

Müller, L. Geschichte der klassischen Philologie in den Niederlanden. Mit einem Abhang über die lateinische Versification der Niederländer, Leipzig, B.G. Teubner, 1869.

Muret, M.-A., The Iuvenilia of Marc-Antoine Muret, ed. K.M. Summers, Columbus, Ohio State University Press, 2006.

[Niceron, J.-P.], Mémoires pour servir à l'histoire des hommes illustres dans la République des Lettres [...], vol. 1, Paris, Briasson, 1729.

Nodell, J.A., Regina, lusus poëticus. Liber alter, Groningen, J. Oomkens, 1777.

Ovid, Les Amours. Texte établi par H. Bornecque, revu par J.-P. Néraudau, Paris, Les Belles Lettres, 1997 . 
Peerlkamp, P.H., Liber de vita doctrina et facultate Nederlandorum qui carmina Latina composuerunt. Editio altera emendata et aucta, Haarlem, V. Loosjes, 1838.

Reland, A., Galatea, lusus poeticus. Amsterdam, sumtibus editoris, 1701.

Reland, A., Galatea. Eene dichterlijke speling. Uit het Latijn in dichtmaat overgebragt en met eenige aanteekeningen, tr. R.G.H. Graadt Jonckers, Utrecht, Van Paddenburg, 1837.

Reland, A., Galatea cum Petri Bosscha notis selectis, ed. C.F.G. Siedhof, Stuttgart, J.F. Cast, 1845 .

Reland, A., Poemata quae hactenus reperiri potuerunt, ed. A. Perrenot, Utrecht, Spruit, 1748.

Reland, A., Relandi Galatea, cum aliorum poëtarum locis comparata a Petro Bosscha Herm. Fil., Amsterdam, P. den Hengst en Zoon, 18 og.

Sannazaro, J., Opera omnia, Douai, Jean Bogard, 1621.

Santen, L. van, Ida, lusus poeticus, Leiden, Cornelis van Hoogeveen jr., 1773.

Santen, L. van, Poëmata, ed. J.H. Hoeufft, Leiden, J. van Thoir, 1801.

Schouten, D., 'Die Ida von Laurens van Santen: Einleitung-Text-Kommentar', Humanistica Lovaniensia, vol. 20, 1971, pp. 267-297.

Schröder, W.A., 'Carl Siedhof, Elegia in obitum F.J. Muelleri (1845). Eingeleitet, herausgegeben, übersetzt und mit Erläuterungen versehen', Neulateinisches Jahrbuch, vol. 13, 2011, pp. 313-343.

Secundus, Johannes, Opera omnia, emendatius et cum notis adhuc ineditis Petri Burmanni Secundi denuo edita, ed. P. Bosscha, Leiden, S. and J. Luchtmans, 1821.

Serrurier, J., Oratio funebris in obitum viri celeberrimi Hadriani Relandi, antiquitatum sacrarum et linguarum orientalium professoris ordinarii, recitata ipsis Nonis Martiis MDCCXVIII, Utrecht, Willem vande Water, 1718.

Stephanus, R.F.H., Lexicographorum principis Thesaurus linguae Latinae in IV. tomos divisus ..., ed. A. Birrius, vol. 1, Basel, E. and J.R. Thurneysen, 1740.

'D'Utrecht', L'Europe savante, vol. 2 pt. 2 (La Haye, avril M.DCC.XVIII), pp. 290-295.

\section{Studies}

Amanti, E.R. D', 'Massimiano e la pseudepigrafia di Pomponio Gaurico', Latinitas, s.n., vol. 7, 2019, pp. 47-64.

Bedaux, J.C., 'Gerhard David Jordens (1734-1803), neulateinischer Dichter aus Deventer' in D. Sacré and J. Papy (eds), Syntagmatia. Essays on Neo-Latin Literature in Honour of Monique Mund-Dopchie and Gilbert Tournoy, Supplementa Humanistica Lovaniensia, vol. 26, Leuven, Leuven University Press, 20o9, pp. 773-79o.

Beer, S. de. 'Ghostwriting in the Renaissance? Giannantonio Campano's Love Elegies for "Diana”, the mistress of Braccio Baglioni', Neulateinisches Jahrbuch, vol. 12, 2010, pp. $41-65$.

Bernays, L., 'Hadrian Relands Lobgedicht auf Lukrez', Neulateinisches Jahrbuch, vol. 17, 2015 , pp. $5^{-21 .}$ 
Consolino, F.E. 'L'elegia secondo Massimiano', in R. Cardini and D. Coppini (eds), Il rinnovamento umanistico della poesia. L'epigramma e l'elegia, Humanistica, vol. 2, pt. 1, Florence, Polistampa, 2009, pp. 183-224.

Dam, H.-J. van, 'Daniel Heinsius' Erstlingswerk. Prolegomena zu einer Edition der Monobiblos', in E. Lefèvre and E. Schäfer (eds), Daniel Heinsius klassischer Philologe und Poet, NeoLatina, vol. 13, Tübingen, G. Narr, 2008, pp. 171-202.

Dam, H.-J. van, 'Second et la poésie néo-latine des Pays-Bas au XVI ${ }^{\mathrm{e}}$ siècle', Les Cahiers de l'Humanisme, vol. 1, 200o, pp. 169-184.

Ferroni, G., Dulces lusus. Lirica pastorale e libri di poesia nel Cinquecento, Manierismo e Barocco, vol. 16, Alessandria, Edizioni dell'Orso, 2012.

Forster, L. The Icy Fire. Five Studies in European Petrarchism, Cambridge, University Press, 1969 .

Gelderblom, W.J.C.M., Secundus' versies. De tekstgenese van Janus Secundus' 'Julia' en 'Basia', PhD thesis, Radboud Universiteit Nijmegen, 2012.

Guépin, J.P., Typisch Nederlands. De Latijnse poëzie, Groningen, Styx, 1993.

Haskell, Y.A., Loyola's Bees. Ideology and Industry in Jesuit Latin Didactic Poetry, Oxford, Oxford University Press, 2003.

Heesakkers, C.L., 'An Lipsio licuit et Cunaeo quod mihi non licet? Petrus Francius and Oratorical Delivery in the Amsterdam Athenaeum Illustre', in G. Tournoy and D. Sacré (eds), Ut granum sinapis. Essays on Neo-Latin Literature in Honour of Jozef IJsewijn, Supplementa Humanistica Lovaniensia, vol. 12, Leuven, Leuven University Press, 1997, pp. 324-351.

Holzberg, N., Die römische Liebeselegie. Eine Einführung, 3rd edn., Darmstadt, Wissenschaftliche Buchgesellschaft, 2006.

Houghton, L.B.T., 'Elegy', in V. Moul (ed.), A Guide to Neo-Latin Literature, Cambridge, Cambridge University Press, 2017, pp. 98-112.

Houghton, L.B.T., 'Renaissance Latin love elegy', in T.S. Thorsen (ed.), The Cambridge Companion to Latin Love Elegy, Cambridge, Cambridge University Press, 2013, pp. 290-305.

Leek, B.H.T.J., Maar ingeboren aard gaat alle dwang te boven. Henricus Bruno, conrector te Hoorn, en zijn Latijnse netwerk in het midden van de zeventiende eeuw, MA thesis, University of Amsterdam, 2013 (https://scripties.uba.uva.nl/scriptie/452835).

Miert, D. van, Illuster onderwijs. Het Amsterdamse Athenaeum in de Gouden Eeuw 16321704, Amsterdam, Bert Bakker, 2005.

Moul, V., 'Lyric Poetry', in S. Knight and S. Tilg (eds), The Oxford Handbook of Neo-Latin, Oxford, Oxford University Press, 2015, pp. 41-56.

Murgatroyd, P. The Amatory Elegies of Johannes Secundus. Leiden, Brill, 2000.

Parker, H.N., 'Renaissance Latin Elegy', in B.K. Gold (ed.), A Companion to Roman Love Elegy, Malden, MA, Wiley-Blackwell, 2012, pp. 476-488.

Ypes, C., Petrarca in de Nederlandse letterkunde, Amsterdam, De Spieghel, 1934. 